\title{
A obra para violão de Ernst Mahle: um panorama histórico e
}

\section{analítico}

\author{
Guilherme Arce | Universidade Estadual de Campinas | Brasil \\ Fábio Bartoloni | Universidade do Estado do Amapá | Brasil
}

\begin{abstract}
Resumo: Ernst Mahle escreveu mais de 20 obras para violão, desde peças para solista até diversas formações de câmara. Além da proposta didática presente em muitas de suas obras, despontam duas características fundamentais que marcam sua escrita violonística: o idiomatismo e a utilização do modalismo folclórico em contraste com materiais composicionais característicos da música do século XX. O presente trabalho se propõe ao estudo da obra violonística de Mahle em três etapas: primeiramente são apresentadas informaçôes sobre as concepções estético-filosóficas de Mahle e como estas se manifestaram na conformação de sua linguagem composicional; em segundo momento são apresentadas informaçôes sobre a relação de Ernst Mahle com o violáo; em terceiro momento é realizado um estudo analítico e histórico de sua obra sob três perspectivas: (a) contextualização histórica das peças; (b) análise dos materiais composicionais utilizados na obra; (c) análise dos idiomatismos presentes na escrita violonística de Mahle, tendo como referencial analítico os trabalhos de Kreutz (2014) e Scarduelli (2007).
\end{abstract}

Palavras-chave: Violão, Ernst Mahle, Idiomatismo.

\begin{abstract}
Ernst Mahle wrote more than 20 pieces for guitar, from soloist works to several distinct chamber music ensembles. Besides the didactic content in many pieces, two fundamental characteristics emerge from his guitar writing: the idiomatism and the use of folkloric modalism in contrast to 20th century music compositional materials. The present work proposes to study Mahle's guitar work in three stages: firstly are presented information on Mahle's aestheticphilosophical conceptions and how these conceptions influenced his compositional language; secondly are presented information about Ernst Mahle's relationship with the guitar; finally, an analytical and historical study of his work is carried out from three perspectives: (a) historical contextualization of the pieces; (b) analysis of the compositional materials used in the work; (c) analysis of the idiomatism in Mahle's guitar writing, using the works of Kreutz (2014) and Scarduelli (2007) as an analytical reference.
\end{abstract}

Keywords: Guitar, Ernst Mahle, Idiomatism. 
obra de Ernst Mahle ${ }^{1}$ é frequentemente associada à musicalização e à música de teor
pedagógico. De fato, uma parte dela carrega esse propósito, sendo um reflexo de sua dupla
atuação como compositor e educador musical. Desde seu período nas classes de composição com Hans-Joachim Koellreutter, na década de 1950, Mahle já atuava em atividades didáticas como seu assistente. No entanto, é a partir da fundação da Escola de Música de Piracicaba² que sua atuação como educador e compositor se intensifica.

Inicialmente, a escrita de obras para estudantes se deu muito em função da pequena disponibilidade de material didático e peças de nível iniciante para as atividades de ensino da escola. Assim, boa parte das composiçóes nesse período foram escritas de modo a atender as demandas da instituição. Como coloca Barros (2005, p. 37): "Inspirado no Mikrokosmos e, em especial, no For Children [de Béla Bartók], Mahle procurou criar um repertório capaz de suprir a falta de material didático disponível para crianças, numa linguagem moderna e com caráter nacional.”

No período inicial da escola, além da escassez de material e peças para estudantes, alguns instrumentos careciam de professores, visto que, em função da baixa demanda, era financeiramente inviável trazer professores de São Paulo para ensinar os alunos. Isso estimulou Mahle ao estudo de diversos instrumentos, tanto com a finalidade de os lecionar quanto de modo a compreender as possibilidades de escrita:

\footnotetext{
Mahle dispôs-se a aprender todos os instrumentos necessários à formação de uma orquestra, para os quais não havia professores em Piracicaba. Já nessa época ele criticava a 'pianolatria' que graçava nas instituiçóes de ensino musical brasileiras e procurava estimular o estudo de instrumentos pouco convencionais, como o contrabaixo, o oboé, a viola etc. $\mathrm{O}$ estudo desses instrumentos fez com que Mahle adquirisse um conhecimento profundo das características técnicas, sonoras e expressivas de cada um deles, o que se reflete na sua obra, frequentemente elogiada por seu 'idiomatismo' (BARROS, 2005, p. 34).
}

Não só as demandas práticas da atuação de Mahle na Escola de Música de Piracicaba foram importantes para a confluência de sua atuação como compositor e educador musical, mas também

\footnotetext{
${ }^{1}$ Os aspectos biográficos de Mahle já foram amplamente abordados em outros trabalhos como: Barros (2005), Costa (2010), Luna (2013), Rahmeier (2014), dentre outros.

2 Fundada na cidade de Piracicaba, SP, no ano de 1953, por Ernst Mahle, Maria Aparecida Mahle e Hans-Joachim Koellreutter inicialmente como uma filial da Escola Livre de Música Pró-Arte. Passaria a ser denominada "Escola de Música de Piracicaba” em 1961.
} 
suas referências musicais e filosóficas. Nesse sentido, duas influências são relevantes: 1) A Antroposofia, uma doutrina místico-filosófica fundada por Rudolf Steiner no século XIX; e 2) a Música Funcional.

O conceito de Música Funcional, é fortemente associado à obra de Paul Hindemith, uma grande referência musical para Mahle. Hindemith defendia que a música deveria ser escrita com um propósito claro, ou ter uma finalidade específica, em lugar de ser simplesmente a realização dos ensejos artísticos dos compositores. Muitas vezes isso se traduzia na escrita de obras com proposta pedagógica. Por outro lado, na Antroposofia existe o conceito de Bildung $g^{3}$ que também é caro a Mahle, pois representa o tipo de formação musical defendido por ele. Em lugar de uma formação tipicamente inspirada nos moldes do século XIX, que valorizam a figura do virtuose solista, Mahle defende a formação mais ampla do estudante de música. Isso se traduz em três características marcantes de sua obra: 1) o elevado número de composições para formações camerísticas e 2) a escrita de obras com pequena dificuldade técnica, sendo acessíveis também a estudantes e 3) a escrita para uma variedade grande de instrumentos, como oposição à predileção tradicional exclusiva pelo piano.

A dupla atuação de Mahle como pedagogo e compositor teve forte influência sobre seu estilo composicional. Mahle o caracteriza como sendo "baseado no modalismo, no folclore e no aleatório controlado" (TOKESHI, 1999, p.43). A utilização de técnicas composicionais características do século XX se deve ao período em que estudou técnicas modernas de composição com Koellreutter ${ }^{4}$. Por outro lado, a utilização do modalismo de inspiração folclórica se deve a dois fatores: a admiração pela obra de Béla Bartók e o pensamento antroposófico. Bartók dedicou boa parte de seus esforços à pesquisa e preservação de gêneros folclóricos da Europa Central, muitas vezes caracterizados pelo uso de materiais modais. Tendo contato com sua obra através de Koellreutter, Mahle teve forte influência pela estética e forma como o modalismo se apresenta na obra do compositor húngaro. Por outro lado, a utilização de material modal e folclórico encontram respaldo nas concepções da Antroposofia. Segundo Costa (2010), Mahle é adepto da pedagogia Waldorf, que se fundamenta sobre conceitos antroposóficos. Sendo assim, afirma:

\footnotetext{
${ }^{3}$ A palavra Bildung é traduzida em alguns textos como "formação cultural” (SUAREZ, 2005). Sinaliza um conceito da Antroposofia que diz respeito a uma ideia ampla de formação. Esta é entendida não apenas enquanto uma formação escolar ou técnica, mas também uma formação da personalidade do indivíduo. 4 "Através dele [Koellreutter] entrou em contato com a música do século XX e com várias técnicas da composição moderna: atonalismo, dodecafonismo, concretismo e música eletrônica.” (ARZOLLA, 1996, p 17).
} 
Para o autor [Rudolf Lanz, 1979], nos contos de fadas estaria presente uma compreensão primitiva do mundo, transmitida simbolicamente através das histórias narradas, funcionando como reflexo das tendências e anseios inconscientes que estão presentes nas crianças. [...] Funcionando como um verdadeiro compêndio de princípios morais e espirituais além de fonte de compreensão histórica, os contos se revestiriam de importância particular por transmitirem '(...) numa forma imaginativa, verdades e realidades de ordem espiritual da humanidade e do indivíduo', pois os mesmos seriam fruto (...) da velha sabedoria popular. Portanto, segundo a Pedagogia Waldorf, por seu valor espiritual e moral a utilização do conto de fadas pedagogicamente, com crianças até oito anos de idade, teria seu espaço validado e, seguindo o mesmo princípio norteador, tanto no campo da prática pedagógica, quanto na esfera composicional propriamente dita, Mahle se voltará para o que, em nossa cultura, seria o correlato dos contos de fadas: o folclore. Para ele, tanto nos contos quanto na música folclórica a manifestação de um homem mais próximo do mundo espiritual estaria latente. (COSTA, 2010, p. 39 - 40)

Em sua obra para violão essa marca se observa no fato de que as composiçóes que carregam uma proposta didática mais evidente são predominantemente elaboradas sobre material folclórico, ao passo que as peças sem uma proposta didática clara se utilizam também das técnicas de composição vanguardistas.

Dentre a vasta produção musical de Mahle, que até o momento soma mais de 2000 obras, 23 foram dedicadas ao violão, em diferentes formações: solos, duos, trios, quartetos, quintetos e obras concertantes. Tendo sua primeira composição para violão escrita em 1967 e a mais recente em 2015, consideramos que sua obra violonística reúne as principais características que marcam sua trajetória musical.

Até o presente momento, sua obra para violão foi objeto de estudo de duas dissertaçóes de mestrado, ambas sobre a Suite para violão solo $(1975)^{5}$ e dois artigos científicos ${ }^{6}$, no entanto, boa parte de sua obra ainda é desconhecida pelos intérpretes. Sendo assim, objetivamos com este trabalho focalizar sua obra escrita para o instrumento, de modo a salientar sua contribuição para o repertório violonístico brasileiro.

\footnotetext{
5 RAHMEIER, 2014. Suite para violão de Ernst Mable: uma edição crítica e de performance. FERNANDES, 2014. Suite para Violão Solo de Ernst Mable: Uma abordagem técnica e interpretativa. ${ }^{6}$ ARCE, 2019. Estudo do Equilibrio sonoro na obra 'Diálogo para violão e cordas de Ernst Mable. RAHMEIER \& AGUIAR, 2013. O processo da escolba de digitação das Três peças para violão (1975) de Ernst Mahle
} 


\section{Questóes Metodológicas}

Como indicado na sessão introdutória, duas características fundamentais da obra de Mahle são a escrita idiomática e o uso de modalismo de inspiração folclórica sobreposto a técnicas composicionais de vanguarda, com exploração de materiais característicos da música do século XX. Sendo assim, as considerações sobre a obra violonística de Ernst Mahle serão realizadas por três perspectivas: (a) levantamento de dados históricos das peças no sentido de contextualizá-las dentro de sua obra; (b) análise do material composicional presente nas peças; e (c) a análise da escrita idiomática para violão.

(a) A primeira perspectiva consiste no levantamento de informaçóes sobre ano de composição, dedicatória, data de estreia, gravaçôes e registros audiovisuais de intérpretes, motivação à escrita da peça (encomenda ou não), dentre outras informaçôes às quais tenhamos acesso e que sejam pertinentes para a contextualização das obras.

(b) A segunda consiste na análise dos materiais composicionais utilizados por Mahle na peça, buscando levantar quais materiais escalares estão sendo utilizados, se a peça emprega uma linguagem predominantemente modal inspirada no folclore ou em técnicas composicionais de vanguarda e se a peça possui uma proposta didática ou não. Aqui buscamos observar uma característica fundamental de sua obra, que se refere à utilização simultânea do modalismo e das técnicas de vanguarda do século XX.

(c) A terceira perspectiva consiste na análise da escrita idiomática. No presente trabalho, o termo “idiomatismo" será utilizado de maneira análoga à encontrada em Scarduelli (2007), segundo o qual, o vocábulo se refere ao:

[...] conjunto de peculiaridades ou convenções que compõem o vocabulário de um determinado instrumento. Estas peculiaridades podem abranger desde características relativas às possibilidades musicais, como timbre, dinâmica e articulação, até meros efeitos que criam posteriormente interesse de ordem musical. (SCARDUELLI, 2007, p. 139)

Os idiomatismos serão investigados tendo como referencial analítico o trabalho de Kreutz (2014), que classifica os recursos idiomáticos em três tipos: (a) Mão Esquerda, (b) Mão Direita e (c) Ambas as Mãos. A esta sistematização iremos acrescentar o conceito de "Recurso Idiomático 
Implícito”, de Scarduelli (2007) e consideraremos também o uso de cordas soltas como uma categoria de idiomatismo adicional. A tabela abaixo sintetiza o exposto, seguida da definição de cada tipo de recurso idiomático.

TABELA DE IDIOMATISMOS

\begin{tabular}{|c|c|c|c|c|}
\hline Categoria & & Recursos Idiomático & & \\
\hline Mão Esquerda & Paralelismo Vertical & Paralelismo Horizontal & Scordatura & - \\
\hline Mão Direita & Fórmulas de Arpejos & Pizzicato & Timbre & $\begin{array}{c}\text { Rasgueados } \\
\text { e Arpejos }\end{array}$ \\
\hline Ambas as Mãos & Percussões & Campanella & - & Harmônicos \\
\hline Cordas Soltas & Cordas Soltas & - & - & - \\
\hline $\begin{array}{l}\text { Recurso Idiomático } \\
\text { Implícito }\end{array}$ & $\begin{array}{c}\text { Escolha de centros, modos } \\
\text { e tonalidades }\end{array}$ & - & - & - \\
\hline
\end{tabular}

Fonte: Elaboração própria a partir de Kreutz (2014) e Scarduelli (2007).

Mão Esquerda: O Paralelismo Vertical se refere a movimentos iguais de mão esquerda realizados em diferentes cordas, ao passo que o Horizontal se refere a movimentos iguais de mão esquerda realizados em diferentes posições da escala do instrumento. Idiomatismo de alteração da Scordatura refere-se aqui à alteração da afinação padronizada do violão, pelo afrouxamento ou tensionamento da(s) tarraxa(s) de modo a se executar intervalos e sons.

Mão Direita: As Fórmulas de Arpejos são padróes de digitação de mão direita repetidos. Pizzicato se refere ao toque que provoca o "abafamento" do som realizado pelo apoio da parte externa da mão direita e dedo mínimo sobre as cordas na região próxima ao cavalete. O idiomatismo de timbre será utilizado em referência aos momentos em que Mahle indica na partitura determinada característica de timbre para o trecho. Os Rasgueados são ataques de mão direita em diversas cordas, geralmente realizados com a parte externa das unhas, realizando padróes rítmicos marcados.

Ambas as Mãos: As Percussóes ou tamboras, consistem em percutir notas ou sons sobre a superfície do instrumento. A Campanella é a "superposição sonora, como sinos, de notas escalares criadas através do uso otimizado de cordas soltas e da digitação de notas sucessivas em cordas adjacentes” (KREUTZ, 2014, p. 6). Os Harmônicos podem ser naturais (cordas soltas) ou artificiais (cordas presas) e proporcionam uma diferenciação de timbre, além de permitirem a utilização de notas mais agudas que as possíveis na escala no instrumento. 
Cordas soltas: Este idiomatismo refere-se ao uso de passagens e acordes com cordas soltas, o que favorece a sonoridade do instrumento por proporcionar maior reverberação em comparação ao toque de notas em cordas presas, além de facilitar a realização de mudanças de posição de mão esquerda.

Recurso Idiomático Implícito: Segundo Scarduelli (2007), este recurso idiomático se refere à escolha de centros, modos e tonalidades que favoreçam a sonoridade do violão pela possibilidade de se utilizar maior número de cordas soltas. Nesse sentido, os outros recursos idiomáticos apresentados anteriormente possuem correspondência com o que Scarduelli (2007) define por "Recursos Idiomáticos Explícitos”.

As obras serão apresentadas por grupos de instrumentação: Solos; Duos; Trios; Quartetos; Quintetos e Obras Concertantes. Tendo em vista o total de 23 obras, as considerações dos materiais composicionais e análises dos idiomatismos da escrita violonística serão realizadas sobre obras selecionadas dentro de cada grupo de instrumentação. Foram utilizados dois critérios para esta seleção: (a) obras escritas originalmente para violão, não sendo incluídas as transcrições ou arranjos para violão e (b) obras que não tenham uma proposta exclusivamente pedagógica. O segundo critério se deve ao fato de que buscamos focalizar mais as questóes associadas aos idiomatismos e materiais composicionais da escrita violonística de Mahle e menos o potencial pedagógico de suas obras.

São importantes também algumas considerações no que se refere ao uso do termo "folclore nordestino" e das referências musicais contidas na obra de Mahle a alguns gêneros musicais praticados na região Nordeste do Brasil. Diversas obras de Mahle se utilizam do modo mixolídio 4+/lídio 7ạdim, o que encontra correspondência com a maneira como esse material modal é abordado em alguns gêneros musicais nordestinos e também com a obra de Bartók, como indica Aloysio de Alencar Pinto: “[...] convém lembrar que uma escala com a $4^{\underline{a}}$ aumentada e a $7 \underline{a}$ abaixada - uma mistura dos dois modos mais característicos do Nordeste - encontra uma relação de perfeita identidade com a escala favorita de Béla Bartók.”(PINTO, 1994, p. 243). Ricardo Tacuchian (1994-95) também observa a utilização de materiais escalares com 4a aumentada e 7a abaixada na música de Béla Bartók, assim como em outras melodias folclóricas da Europa Central ${ }^{7}$.

Sobre as similaridades entre o material modal de Bartók e da música nordestina, Mahle afirma

\footnotetext{
${ }^{7}$ Ver: TACUCHIAN, Ricardo. (1994-95) Estrutura e estilo na obra de Béla Bartók. Revista Brasileira de Música n. 2; p. $1-17$.
} 
em entrevista:

[...]antes de vir ao Brasil consegui ainda chegar a ter um contato com a música de Béla Bartók. [...] achei maravilhoso o que ele descobriu, na Europa Oriental, de música modal. O que tem na Romênia, estes duetos para violino e em 'For Children' para piano e muitas outras peças onde ele usa esse folclore ou o tipo do folclore da Europa. Quando conheci o nordestino brasileiro, depois cheguei à conclusão que pode pôr um do lado do outro que um é de tanto valor como o outro. (RAHMEIER, 2014, p. 88)

Além dos materiais modais, outro tipo de referência a alguns gêneros musicais nordestinos se dá pelo uso frequente de terças paralelas em desenhos melódicos. Sobre esta questão, Farias (2003), em uma análise da obra "Marcha da Estrada” de Guerra-Peixe, indica que melodias por terças paralelas são comumente exploradas pelos pífanos das 'zabumbas' nordestinas:

As duas flautas começam a apresentar o tema principal desse movimento, tocando em terças paralelas à maneira dos pífanos da zabumba nordestina. Ressalte-se aqui, conforme esclarece Guerra-Peixe (1958), que "o nome 'zabumba' não indica apenas o bombo popular. Pelo menos no Nordeste, 'Zabumba' é também uma orquestra típica daquela região cultural. (FARIAS, 2003, p. 118)

\section{A obra para violão}

A característica do idiomatismo na escrita violonística de Mahle levanta o questionamento sobre o conhecimento do compositor acerca do violão. Em entrevista a Rahmeier (2014), o compositor indica que estudou alguns métodos de violão, embora não tenha se aprofundado, visto que ao início da Escola de Música, segundo ele, havia grande número de professores do instrumento em Piracicaba. Dentre estes, o violonista Sérgio Belluco era o responsável pelas aulas de violão na escola. Sendo assim, ao contrário de muitos outros instrumentos, o estudo do violão se deu não com uma proposta de ensinar, mas sim de compreender suas capacidades visando a composição.

A princípio Mahle não nutria tanto interesse pelo instrumento. Foi somente a partir de 1967, quando se propôs a escrever a primeira peça para canto e violão, que o compositor começou a dedicálo maior atenção. Sabe-se também que seu primeiro contato com violonistas se deu com os que residiam em Piracicaba, embora tivesse presenciado um concerto de Andrés Segovia anteriormente no teatro Cultura Artística, como descreve no relato: 
Em um trabalho meu sobre interpretação mencionei o mais famoso violonista espanhol, Andrés Segovia. Eu o escutei em São Paulo. Era inverno e na Cultura Artística tinha um teatro de mil e duzentos lugares, isso é muito grande. Mas daí, como era inverno, muitas pessoas estavam tossindo, barulho de papel de bala. Ele começou a tocar e logo falou; "assim não é possível” e saiu do palco. Depois de um minuto ele voltou e foi um silêncio absoluto. $\mathrm{O}$ artista tem que exigir isto! (RAHMEIER, 2014, p. 91)

Das obras que incluem o violão, a primeira foi escrita em 1967 e a mais recente em 2015. Escreveu duas obras para violão solo, mas predominam composiçốes para música de câmara, sendo as formaçốes para duo mais numerosas: violão e voz, violão e piano, violão e violino e duo de violóes. Há três obras para trio e uma peça para quarteto, sendo esta sua obra mais recente. Para quinteto, Mahle arranjou obras escritas anteriormente para outros grupos como o Diálogo para violão e cordas (1971), originalmente para violão e orquestra de cordas e Ou isto ou aquilo (1981), originalmente para voz e piano. Seu catálogo inclui também três obras concertantes para violão: o já mencionado Diálogo para violão e cordas (1971), Concertino sobre um tema espanbol (1970) e Concertino (2010).

Todas as obras para violão são editadas pelo próprio compositor, sendo comercializadas por meio da Associação Amigos Mahle. A maior parte das gravações são não comerciais, mas as peças Diálogo para violão e cordas (1971) e Moto Perpétuo e Rapsódia - que integram a Suite (1975) - foram gravadas em CD pelo violonista Marcus Llerena ${ }^{8}$. Além destas gravações comerciais, há também uma gravação realizada por Francesco Biraghi (violão) e Tầnia Camargo Guarnieri (violino) da Sonata (1985). A peça com maior número de registros audiovisuais e gravações encontradas é o Diálogo para violão e cordas (1971), seguido da Sonata (1985). A tabela contida no Anexo I sintetiza as gravaçóes e registros audiovisuais de sua obra violonística encontradas até o momento. A Tabela 1 abaixo reúne seu catálogo de obras para violão.

TABELA 1 - Obra para Violão de Ernst Mahle.

\begin{tabular}{cccc}
\hline & Formação & Título & Ano \\
\hline \multirow{2}{*}{ Solo } & Violão Solo & As melodias da Cecília & 1972 \\
& & Suite & 1975 \\
\hline \multirow{3}{*}{ Duos } & Duo de Violóes & Duetos Modais & 1985 \\
& Violino e Violão & Sonata & 2015 \\
& Violão e Piano & Sonatina & \\
\hline
\end{tabular}

\footnotetext{
${ }^{8}$ Ver Anexo I.
} 
TABELA 1 - (cont.) Obra para Violão de Ernst Mahle.

\begin{tabular}{|c|c|c|c|}
\hline & Formação & Título & Ano \\
\hline \multirow{7}{*}{ Duos } & \multirow{7}{*}{ Canto e Violão } & Duas peças para canto e violão - Soprano & 1967 \\
\hline & & Natal-Baritono ou Mezzo-soprano & 1987 \\
\hline & & Quadras ao gosto popular - Baritono ou Mezzo- & 1981 \\
\hline & & soprano & \\
\hline & & Quadras ao gosto popular - Soprano ou Tenor & 1981 \\
\hline & & Leilão de Jardim - baritono ou mezzo-soprano & 1991 \\
\hline & & Leilão de Jardim - tenor ou soprano & 1991 \\
\hline \multirow{3}{*}{ Trios } & Soprano, flauta e violão & Duas peças para canto, flauta e violão & 1974 \\
\hline & Violino, violoncelo e violão & Trio para Violino, violoncelo e violão & 1992 \\
\hline & Flauta, violino e violão & Trio para Flauta, violino e violão & 1995 \\
\hline \multirow{5}{*}{ Quartetos } & \multirow{4}{*}{$\begin{array}{c}\text { Trio vocal (soprano, mezzo-soprano, } \\
\text { contralto) e Violão }\end{array}$} & Quadras ao gosto popular & 1981 \\
\hline & & Ou isto ou aquilo & 1981 \\
\hline & & Leilão de Jardim & 1981 \\
\hline & & Figurinhas & 1981 \\
\hline & Quarteto de Violóes & Quarteto para violóes & 2015 \\
\hline \multirow[t]{2}{*}{ Quintetos } & $\begin{array}{c}\text { Soprano, flauta, oboé, violoncelo e } \\
\text { violão }\end{array}$ & Ou isto ou aquilo (transcr) & \\
\hline & Violão e Quarteto de Cordas & Diálogo para violão e cordas (transcr.) & 2017 \\
\hline \multirow{3}{*}{$\begin{array}{l}\text { Violão e } \\
\text { Orquestra } \\
\text { de Cordas }\end{array}$} & \multirow{3}{*}{ Violão e Orquestra de cordas } & Concertino sobre um tema espanbol & 1970 \\
\hline & & Diálogo para violão e cordas & 1971 \\
\hline & & Concertino & 2010 \\
\hline
\end{tabular}

Fonte: Catálogo de Obras de Ernst Mahle (2018).

\subsection{Violão Solista}

A partir da observação das peças que integram seu catálogo para violão, podemos notar que algumas têm clara proposta pedagógica e outras não possuem tal caráter. Para violão solo Mahle escreveu duas peças: As Melodias da Cecilia (1972) e Suite (1975). Já aqui nota-se a diferença considerável de abordagens. A primeira foi escrita para diversas formaçóes, dentre as quais, violão solista. Consiste em 10 peças ${ }^{9}$ elaboradas sobre melodias que a filha do compositor criou durante sua infância. De nível iniciante, com temática infantil e proposta pedagógica, as peças exploram material com teor nacional, inspirados em cantigas de roda. Estas obras se utilizam das técnicas convencionais

\footnotetext{
9 "Despertar das Flores”; "Estória Melancólica”; "Festa na Fazenda”; "Na Floresta”; "Anão e Fada”; "O Passeio no Bosque"; "Potrinho Caprichoso"; "Saudades da Mamãe"; "Valsa Campestre”; "Valsa da Rosa”.
} 
de violão e muitas podem ser tocadas predominantemente sobre a primeira posição do instrumento.

A segunda obra, Suite (1975), difere bastante da anterior. É descrita pelo violonista Fábio Zanon como "sua obra mais ambiciosa". (ZANON, 2007, s/n). Essa obra explora uma série de técnicas expandidas e idiomatismos, como Percussóes, Pizzicatos Bartók e a alteração da Scordatura do instrumento ao longo da peça como efeito sonoro. Ao contrário do modalismo característico de outras obras, Mahle explora séries dodecafônicas, passagens atonais, clusters e harmonias quartais. Considerando a maneira como tais elementos são apresentados na peça e a partir de entrevista concedida a Fernandes (2014), sabemos que Mahle não empregou uma proposta didática na Suite $(1975)^{10}$.

Mahle afirma que a Suite (1975) provavelmente fora escrita a partir de uma encomenda feita por algum dos violonistas que passaram pela Série Cultura Artística, com os quais teve contato. Sobre a linguagem empregada na obra, Mahle afirma que buscava "manter o meio entre a vanguarda e a música popular. [...] um pouco de música folclórica e também algo de música moderna, que explore coisas novas”. (RAHMEIER, 2014, p. 112).

A dedicatória da obra estava no primeiro manuscrito, que se perdeu, portanto, não se tem certeza sobre essa informação. Embora todos os movimentos da Suite (1975) já estivessem escritos, Mahle utilizou três dos seis movimentos sob o nome de Três Peças para Violão para participar de um concurso em 1978: Diálogo, Monólogo e Moto Perpétuo. Até o momento, encontra-se uma gravação comercial de dois dos seis movimentos no CD de Marcus Llerena, citado anteriormente, além de dois registros não comerciais, realizados pelos violonistas Álvaro Henrique e Vinícius Lucena Fernandes.

A Suite (1975) é formada de seis movimentos: Rapsódia, Passacale, Diálogo, Moto Perpétuo, Monólogo e Ostinato. O primeiro movimento parte de uma ideia que contrapóe acordes dissonantes a blocos de clusters e trinados (Fig.1).

\footnotetext{
${ }^{10}$ Questionado sobre a obra, no que se refere a algum propósito didático, Mahle afirma: "nesta suíte não há nenhuma intensão didática. É tão difícil que um principiante não vai pôr a mão”. (FERNANDES, 2014, p. 13).
} 
FIGURA 1 - Rapsódia. Compassos $1-4$.

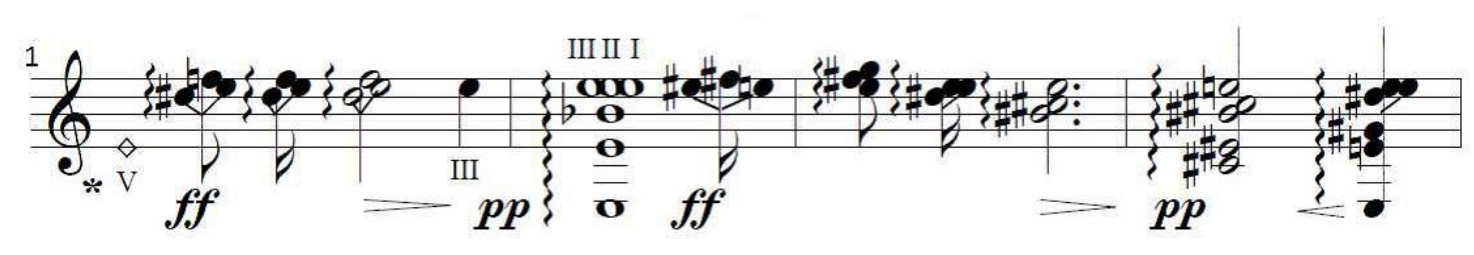

Fonte: MAHLE (1975 a)

No trecho abaixo Mahle explora dois tipos de idiomatismos: Paralelismo Vertical, pela execução de ligados na primeira casa da escala alternadamente entre as seis cordas do instrumento, e de Percussão, com marcação de tambora, ao final da passagem.

FIGURA 2 - Rapsódia. Compassos 7 -15.
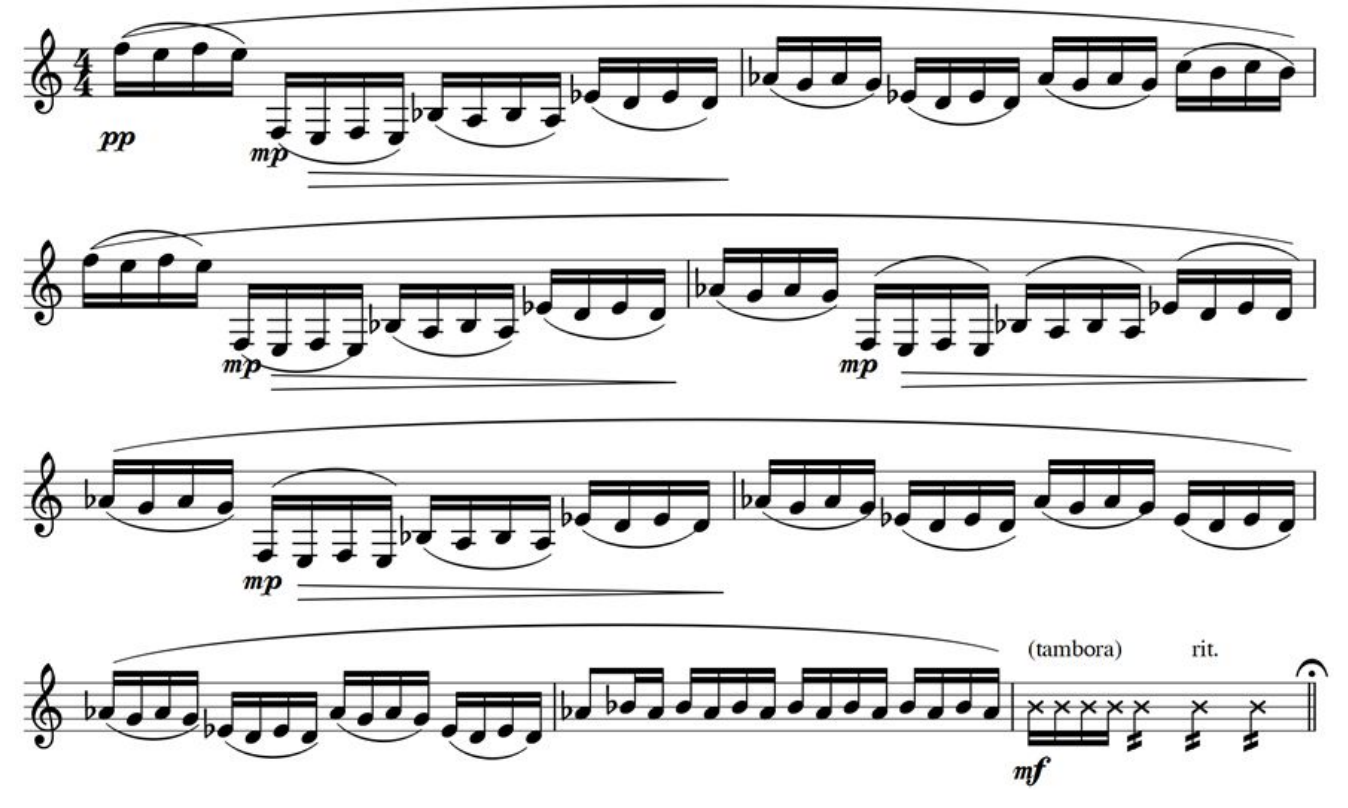

Fonte: MAHLE (1975 a)

No segundo movimento, Passacale, o material composicional se fundamenta em um ostinato com intervalos de semitom no baixo, executados a partir de um idiomatismo de Scordatura. Os intervalos são tocados pelo tensionamento e afrouxamento da corda pelo mecanismo da tarraxa. Isso vem sugerido pelo asterisco marcado na pauta, com a seguinte notação: "girando a tarraxa”. Além deste, há também o uso do idiomatismo de mão direita do Pizzicato Bartók no primeiro compasso: 
FIGURA 3 - Passacale. Compassos 1 - 2.

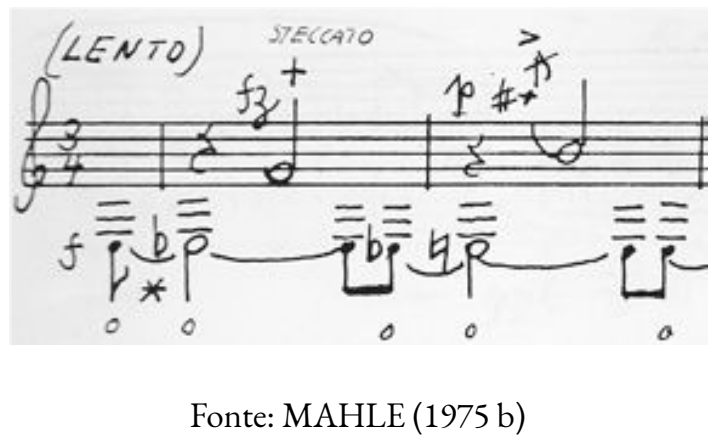

Mahle explora também o idiomatismo de Harmônico, que encerra o movimento:

FIGURA 4 - Passacale. Compassos 32 - 33.

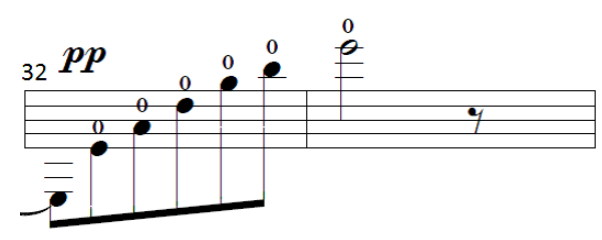

Fonte: MAHLE (1975 a)

O terceiro movimento, Diálogo, explora a contraposição entre dois elementos: passagens de oitavas paralelas com dinâmica $f$ (Fig. 5a); e passagens com acordes formados por intervalos de terças e quartas em dinâmica $p$ (Fig. 5b). Os idiomatismos explorados aqui são de Paralelismo Horizontal. Ilustrados na figura $5 \mathrm{~b}$ os acordes são realizados pelo movimento horizontal da mesma forma de mão esquerda.

FIGURA 5a - Diálogo. Compasso 1.

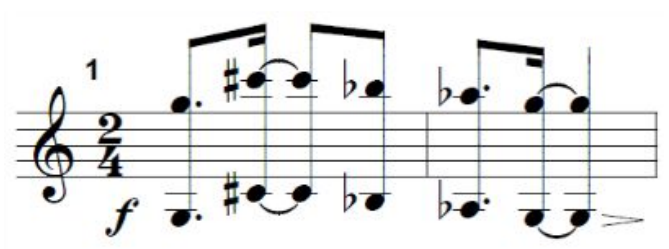

Fonte: MAHLE (1975 a) 
FIGURA 5 b - Diálogo. Compassos $3-4$.

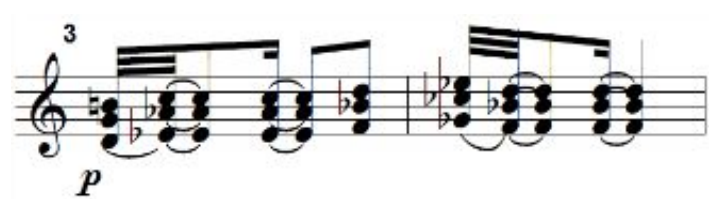

Fonte: MAHLE (1975 a)

O quarto movimento, Moto Perpétuo, se fundamenta em compassos de 5/8, preenchidos com colcheias em intervalos de segundas, terças e quartas. A utilização de trechos escalares cromáticos é intercalada com a ampliação do registro gradualmente a partir do desenho melódico formado pelas colcheias.

FIGURA 6 - Moto Perpétuo. Compassos 1 - 6.

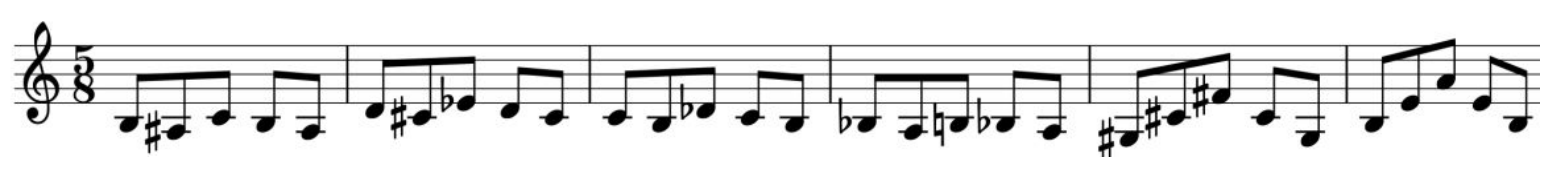

Fonte: MAHLE (1975 a)

A partir do compasso 14 observa-se o recurso idiomático de Paralelismo Horizontal, pelo movimento ao longo da escala com a mesma forma de mão esquerda que utiliza pestanas.

FIGURA 7 - Moto Perpétuo. Compassos 14 - 18.

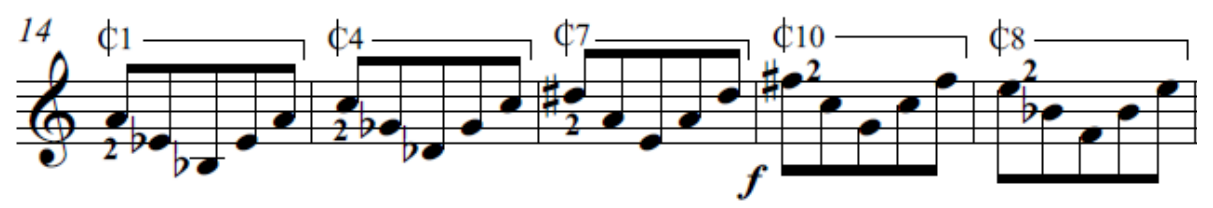

Fonte: MAHLE (1975 a)

O quinto movimento, Monólogo, contrapóe dois elementos: o primeiro constituído de acordes de três notas e o segundo formado por passagens em semicolcheias e colcheias. 
FIGURA 8 - Monólogo. Compassos 1 - 3 .

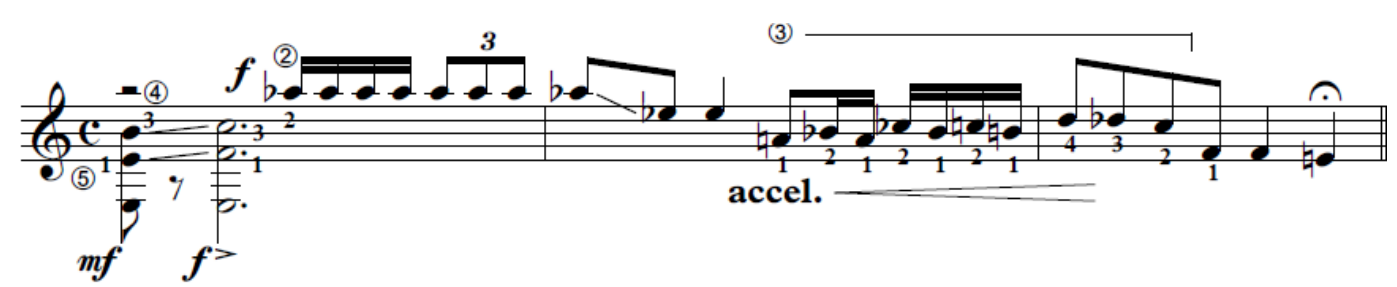

Fonte: MAHLE (1975 a).

Mahle também utiliza o idiomatismo de Harmônicos, no compasso 25 ilustrado abaixo:

FIGURA 9 - Monólogo. Compassos 22 - 26.

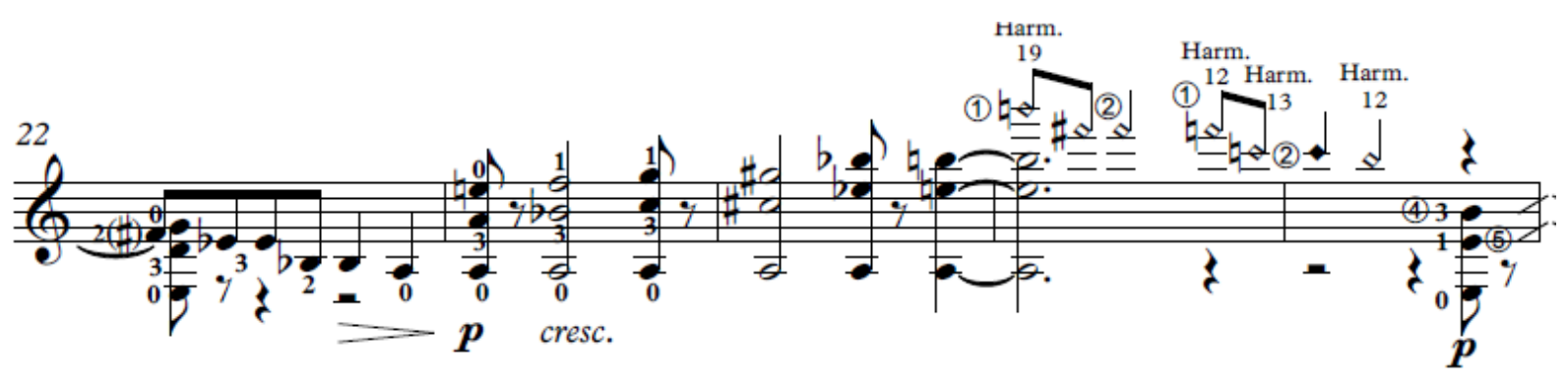

Fonte: MAHLE (1975 a)

O sexto e último movimento, Ostinato, é construído sobre uma série dodecafônica com compassos de $7 / 8$ e 5/8. Nesta peça, a afinação da terceira corda é alterada para Fá\#. O trecho abaixo indica a série dodecafônica utilizada por Mahle.

FIGURA 10 - Ostinato. Compassos 1 e 2.

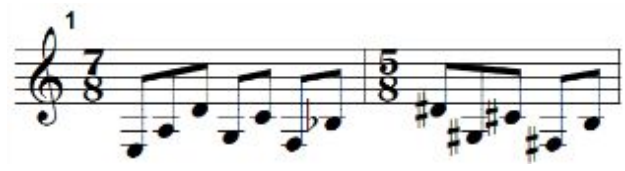

Fonte: MAHLE (1975 a).

Neste movimento Mahle emprega um idiomatismo de Timbre, pela marcação "1a vez atadilho, 2 a vez roseta”, indicando a região da corda que deve ser tocada em cada apresentação do trecho (Fig. 


\section{FIGURA 11 - Ostinato. Compassos 1 e 2.}

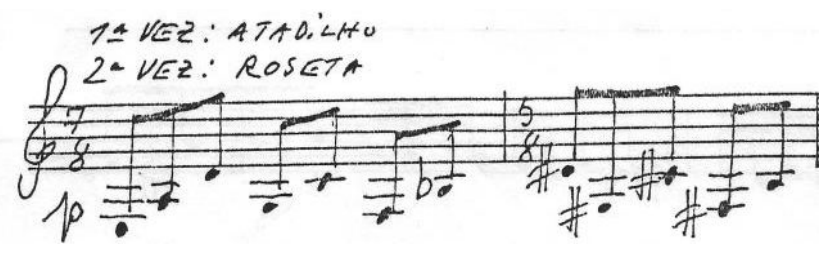

Fonte: MAHLE (1975 b).

\subsection{Duos}

A maior parte da obra de Mahle para violão, é dedicada à formação de duo. Sua obra mais recente é o conjunto de Duetos modais (2015), para duo de violóes. Estas peças ainda não possuem gravações comerciais, mas encontramos registros audiovisuais realizados pelos violonistas Beatriz Virgínia e Gabriel Costa ${ }^{11}$. Dedicados ao violonista Turíbio Santos, são oito peças curtas que se fundamentam sobre materiais escalares distintos. A tabela abaixo ilustra os duetos e seus materiais escalares.

TABELA 2 - Duetos modais e seus materiais escalares.

\begin{tabular}{ccc}
\hline Dueto No & Andamento & Material Escalar $^{\mathbf{1 2}}$ \\
\hline $\mathbf{1}$ & Adagio & Lídio-mixolídio \\
$\mathbf{2}$ & Moderato & Modo Cigano \\
$\mathbf{3}$ & Andante/Allegretto & Tritonal Maior Hexatônico \\
$\mathbf{4}$ & Allegretto & Tons Inteiros \\
$\mathbf{5}$ & Lento & Frígio-Dórico \\
$\mathbf{6}$ & Moderato & Octatônico Regular \\
$\mathbf{7}$ & Andante/Adagio/Vivace & Tritonal Menor \\
$\mathbf{8}$ & Allegro & Falsa relação harmônica \\
\hline
\end{tabular}

Fonte: Elaboração própria a partir da partitura da obra.

Mahle escreveu duetos modais para inúmeros instrumentos e segundo o próprio compositor, são obras com propósito pedagógico. Os utilizava nas aulas, de modo que os alunos tocassem as escalas

\footnotetext{
${ }^{11}$ Ver Anexo I.

${ }^{12}$ Os materiais escalares de cada peça são apresentados em uma pauta no rodapé da partitura, colocados pelo próprio compositor.
} 
antes de interpretar os duetos, geralmente acompanhados por Mahle ao piano (RAHMEIER, 2014, p. 89). Os duetos para violão são constituídos predominantemente de escalas e não exploram técnicas expandidas como a Suite (1975) ou o Diálogo para violão e cordas (1971). Algumas passagens são características de sua obra, como a utilização de terças paralelas em desenhos melódicos, de maneira alusiva a gêneros da música folclórica nordestina. $\mathrm{O}$ compasso 21 ilustrado na figura 12 exemplifica seu uso.

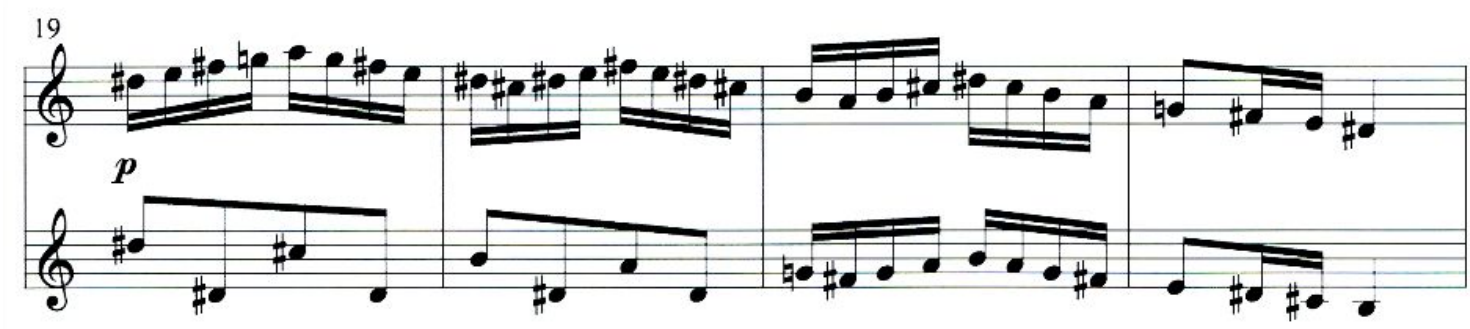

Fonte: MAHLE (1975 a).

Embora sejam duetos com proposta didática, Mahle não apresenta uma escrita com a utilização ampla dos idiomatismos anteriormente apresentados.

Ainda no que se refere às formações de duos, sabemos que uma de suas obras mais visitadas pelos intérpretes é a Sonata (1985), para violino e violão. Esta peça possui uma gravação comercial, realizada por Francesco Biraghi (violão) e Tânia Camargo Guarnieri (violino) no CD "Viaggio a colori”, de 2009. Além desta, encontramos alguns registros audiovisuais e gravaçóes em programas de rádio e plataformas digitais ${ }^{13}$. Sobre a peça, Zanon (2007) afirma:

Na obra de Mahle é difícil dizer se ele busca uma forma que dê revestimento ao material de base folclórica, ou se este material é escolhido por melhor suprir as necessidades de uma estrutura pré-estabelecida. O resultado é uma música inusitadamente homogênea para um compositor de base eclética, redondinha, descomplicada, como esta sonata para violino e violão de 1985, onde o material de sabor nordestino é perfeitamente adaptado aos contrastes dramáticos da forma sonata. O último movimento é uma espécie de xaxado, que é interrompido por uma valsa quase minueto, uma marca registrada do humorismo de Mahle. (ZANON, 2007, s/n)

\footnotetext{
${ }^{13}$ Ver Anexo I
} 
A obra foi dedicada ao "duo Paganini” formado por Francesco Biraghi (violão) e Fernando Antonelli (violino). Possui também uma versão para trio de flauta, violino e violão escrita em 1995. Trata-se de uma peça sem proposta didática, tendo em vista a maior densidade musical e técnica apresentada na parte do violão e nas interaçốes com o violino.

Os três movimentos que integram a obra são: Allegro Moderato, Andantino e Vivo. Mahle utiliza passagens com material modal mixolídio/lídio, escalas octatônicas, de tons inteiros e passagens cromáticas. No primeiro movimento há exploração de material folclórico alusivo a melodias do gênero baião, como nos compassos 31-33, em que se apresenta no violino uma melodia com material de Mib lídio com a sétima abaixada (Fig. 13).

FIGURA 13 - Sonata. I. Allegro Moderato. Compassos 29 - 40.
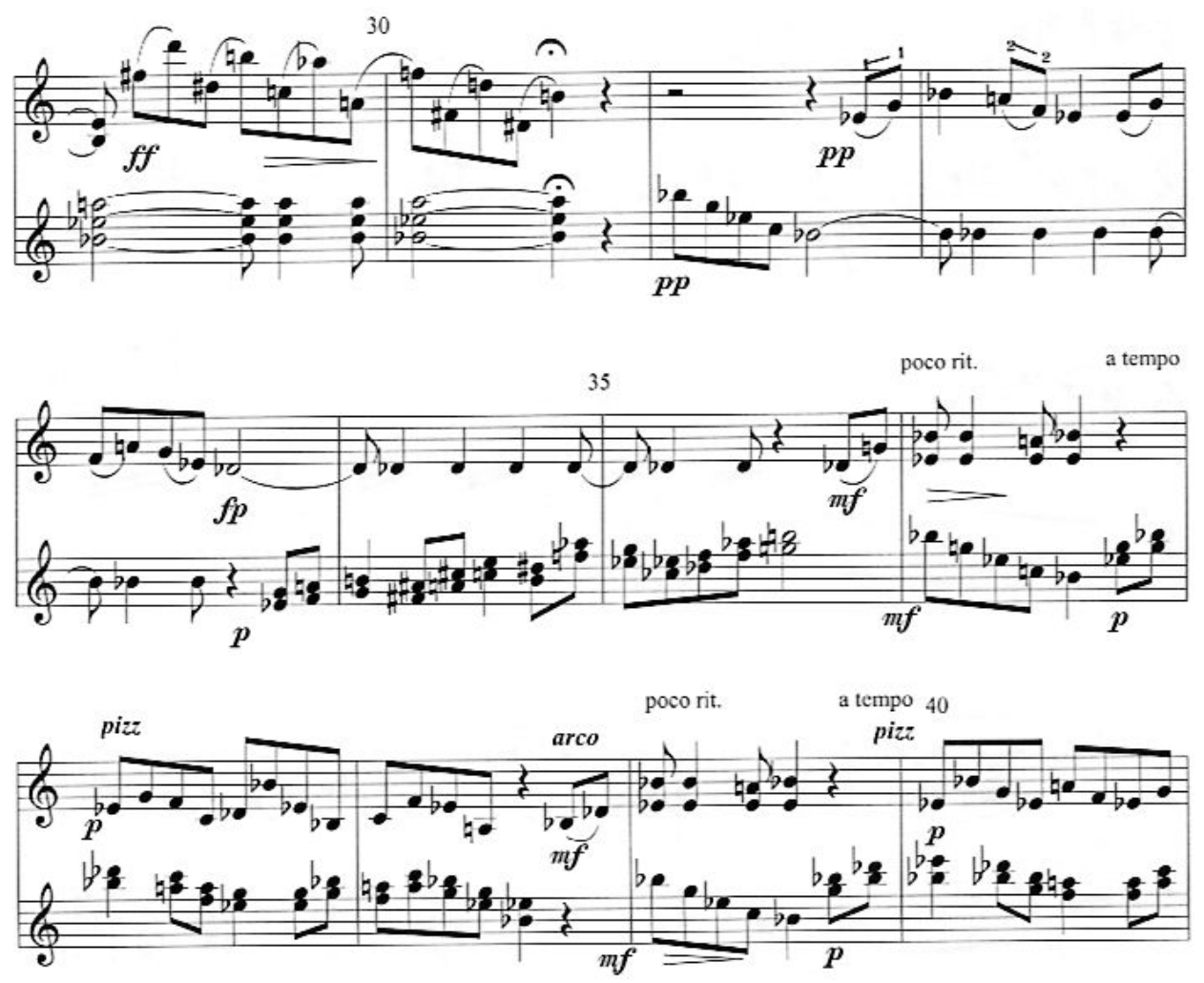

Fonte: MAHLE (1985)

A mistura entre esses materiais ocorre em diferentes passagens, como indicado também na figura 13 acima. A partir do compasso 33.4, a apresentação de melodias por terças paralelas no violão faz referência à maneira como as terças paralelas são utilizadas em alguns gêneros de música folclórica nordestina, no entanto, o material utilizado é cromático o que proporciona uma sonoridade 
contrastante com as terças paralelas dos compassos 36.4 - 38, que apresentam material escalar lídio com sétima abaixada.

No compasso 46 é apresentado um segmento com material octatônico de Mi, logo após uma sequência que utiliza material modal.

FIGURA 14 - Sonata. I. Allegro Moderato. Compassos 29 - 40.

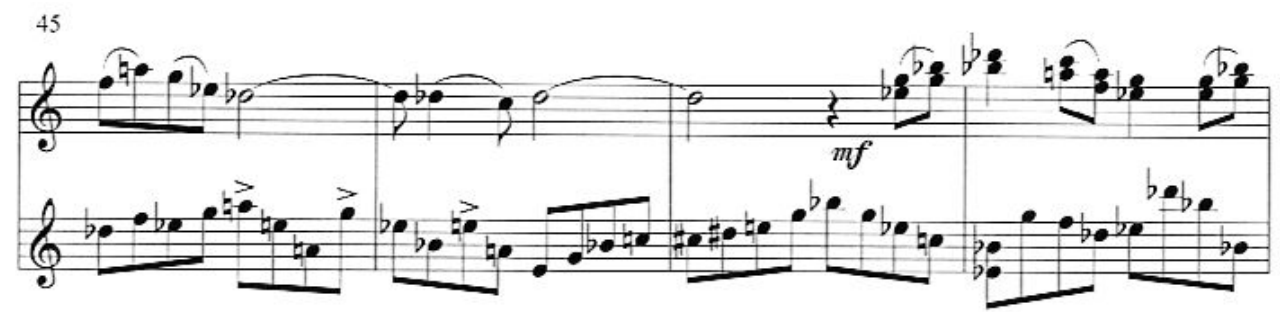

Fonte: MAHLE (1985)

No segundo movimento, Andantino, observa-se novamente a utilização de terças paralelas alusivas ao folclore. No entanto, as terças são apresentadas em desenho cromático ascendente.

FIGURA 15 - Sonata. II. Andantino. Compassos 15 - 17.

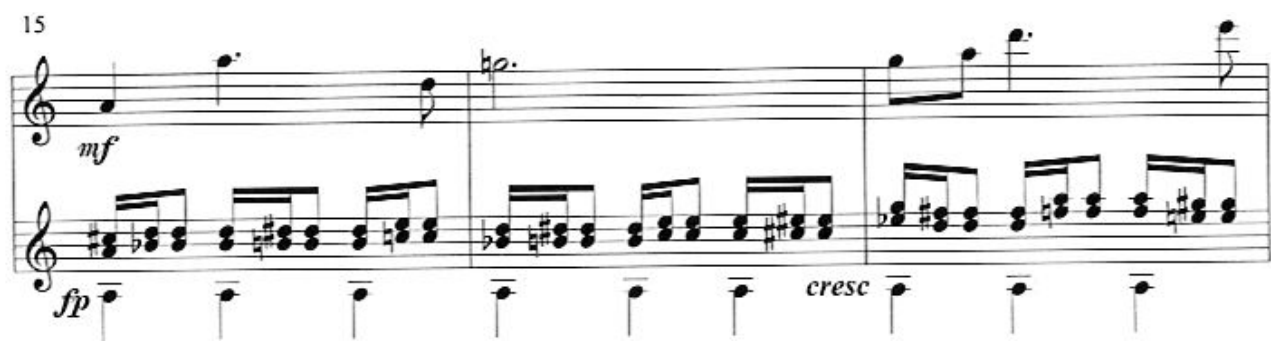

Fonte: MAHLE (1985)

O terceiro movimento explora dois ambientes musicais distintos, um alusivo ao ritmo do baião, o que se observa pela célula rítmica apresentada na abertura do movimento pelo violão (ver fig. 16, segunda pauta), e outro com estrutura rítmica de valsa em compasso 3/8 e marcação de "poco meno vivo”. No que se refere aos matérias composicionais apresentados, Mahle utiliza material menor melódico, modal e de tons inteiros. $\mathrm{Na}$ abertura do movimento observamos a utilização de material de Mi menor melódico: 
FIGURA 16 - Sonata. III. Vivo. Compassos 1 - 4.

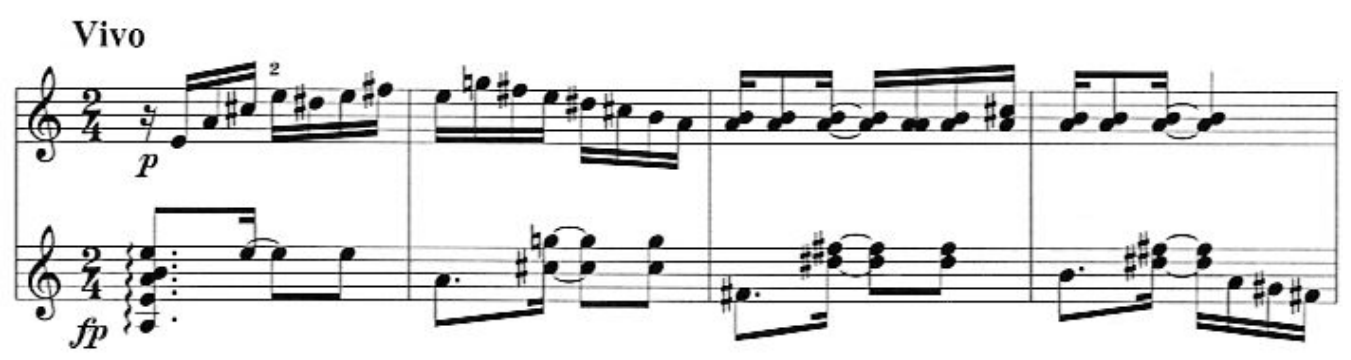

Fonte: MAHLE (1985)

No compasso 17 se inicia uma passagem escalar de tons inteiros no violão que é acompanhada em seguida pelo violino, formando mais uma vez uma sequência de terças paralelas:

FIGURA 17 - Sonata. III. Vivo. Compassos 17 - 20.

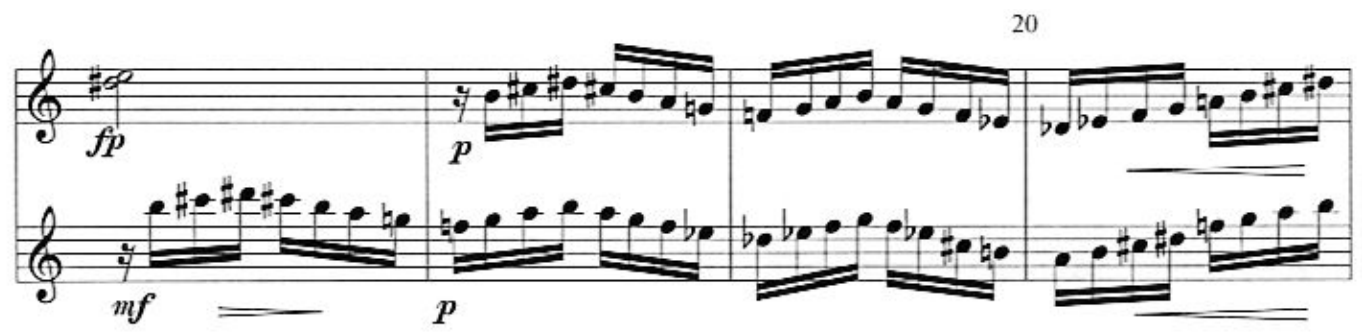

Fonte: MAHLE (1985)

No tocante aos recursos idiomáticos do violão, Mahle explora Paralelismos Horizontais, Harmônicos, acordes com Cordas Soltas e o Idiomatismo Implícito pela escolha de determinados centros tonais. Principalmente no segundo movimento, há ampla exploração de harmônicos naturais (Fig. 18, c. 1 - 3) e acordes com cordas soltas (Fig 18, c. 8).

FIGURA 18 - Sonata. II. Andantino. Compassos 1 - 3; 7 - 8 .

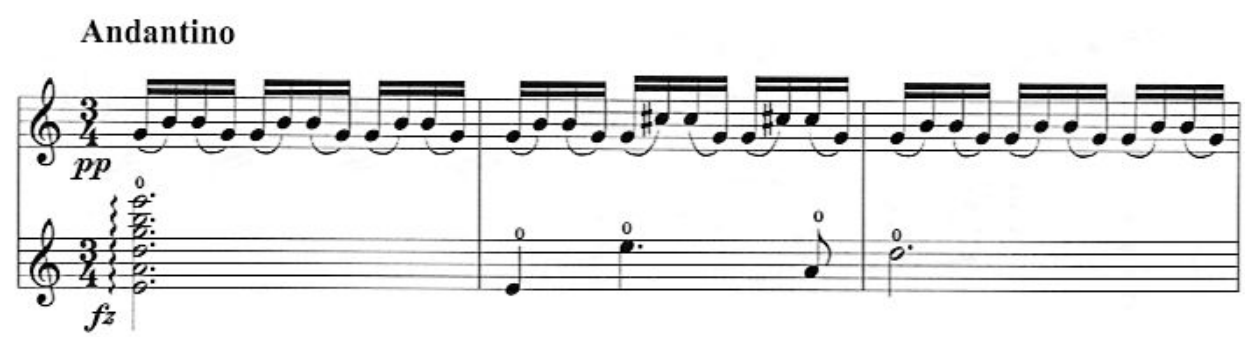


FIGURA 18 - (cont.) Sonata. II. Andantino. Compassos 1 - 3; 7 - 8.

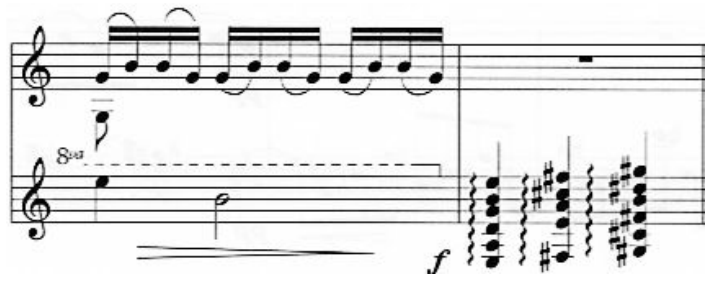

Fonte: MAHLE (1985)

O idiomatismo implícito se observa na utilização de passagens com polaridade sobre Lá, como no stretto que encerra o terceiro movimento:

FIGURA 19 - Sonata. III. Vivo. Compassos 173 - 176.

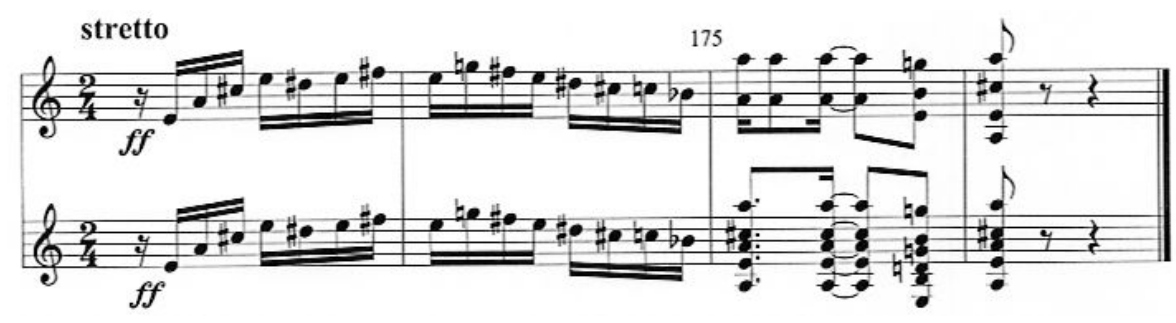

Fonte: MAHLE (1985)

Outra obra para duo de Mahle é a Sonatina (2015), para piano e violão, uma de suas obras mais recentes. A peça foi dedicada ao violonista norte-americano Jeff Anvinson. Foi estreada em 2016 pela esposa do compositor, a pianista Maria Aparecida Mahle, e pelo violonista Gerelmager Gonçalves no 75o aniversário da Escola de Música de Piracicaba. A obra possui um registro em áudio executado por Gerelmager Gonçalves (violão) e Maria Aparecida Mahle (piano) ${ }^{14}$. É dividida em três movimentos: Prelúdio, Interlúdio e Burlesque. O prelúdio explora a alternância entre violão e piano na exposição de temas melódicos em tercinas, caminhando por diferentes regióes harmônicas. O segundo movimento se fundamenta em passagens com escalas octatônicas e materiais modais. O terceiro movimento, Burlesque, utiliza material menor melódico e octatônico, apresentando temas de caráter humorístico e dançante. Nesta obra a escrita violonística não explora os idiomatismos característicos da obra de Mahle e acreditamos que não apresente grandes desafios técnicos quando comparada a outras obras como a Suite (1975).

\footnotetext{
${ }^{14}$ Ver Anexo I.
} 
Para duo, Mahle escreveu também diversas canções para violão e voz. Quadras ao Gosto Popular é uma delas. Escrita em 1981, foi dedicada ao cantor lírico paraguaio Eladio Pérez Gonzáles, com versões para diversas formações, sendo uma delas para violão e voz. Ainda não há registros ou gravações da obra em sua versão para violão ${ }^{15}$. Difere consideravelmente de qualquer outra canção escrita pelo compositor. A obra reúne 8 canções curtas, tocadas sem interrupção, elaboradas sobre seleções do texto homônimo de Fernando Pessoa. Se assemelham à estrutura de modinha, não fazendo referência ao folclore pelo modalismo nem aos materiais vanguardistas característicos de grande parte de sua obra. O violão neste contexto assume papel exclusivamente de acompanhador. Outras cançóes como Leilão de Jardim (1971), escrita sobre texto infantil homônimo de Cecília Meirelles e Natal (1987), sobre o texto Poema de Natal, de Vinícius de Moraes possuem temáticas e propostas didáticas, associadas ao trabalho de musicalização. A canção Natal possui um registro audiovisual realizado pelo violonista Renato Mendes e a soprano Luísa Voigt. Também foi escrita para outras formações além de violão e canto.

Dentre as cançốes escritas por Mahle, destacamos as Duas Peças para Canto e Violão (1967): Epigrafe e Queixa da Moça Arrependida. Foram escritas sobre textos homônimos de Guilherme de Almeida e Ribeiro Couto e datam de uma fase composicional inicial, em que as peças não se utilizam tanto do material modal mais característico das obras posteriores à década de 1970, predominando o atonalismo. Ainda não possuem registros ou gravaçóes de intérpretes. No acompanhamento de violão, Mahle utiliza acordes com intervalos dissonantes, arpejos em quintinas, percussões sobre as cordas e harmonias quartais. Sua execução pode apresentar algumas dificuldades do ponto de vista musical, não tendo, portanto, um caráter pedagógico como as outras obras para violão e voz.

Estas canções exploram as especificidades idiomáticas do violão como elementos estruturantes da obra. Em Epígrafe, fica claro que a elaboração harmônica da peça se deu a partir das possibilidades expressivas do violão, o que se observa no fato de que a maior parte dos acordes utilizam seis notas, com maioria das notas em cordas soltas ou em pestanas, permitindo seu toque em Rasgueo. Isso se observa já na introdução da primeira canção:

\footnotetext{
${ }^{15}$ Existe um registro da canção com acompanhamento de piano: https://www.youtube.com/watch?v=P81fux1049c . Último acesso em 25/10/2020.
} 
FIGURA 20 - Epigrafe (1967). Compassos 1- 4.

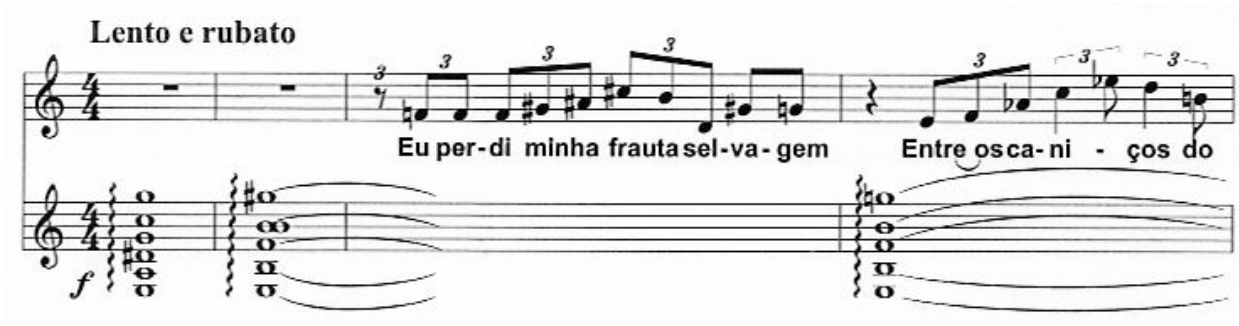

Fonte: MAHLE (1967)

Ao violão é atribuído não apenas um papel harmônico, no intuito de acompanhar ou ambientar a melodia, mas também de introduzir efeitos sonoros. Nesses casos, Mahle explora os idiomatismos do instrumento, como o motivo do compasso 6, que se utiliza de um ligado a partir da segunda corda solta:

FIGURA 21 - Epigrafe (1967). Compassos 5 - 6.

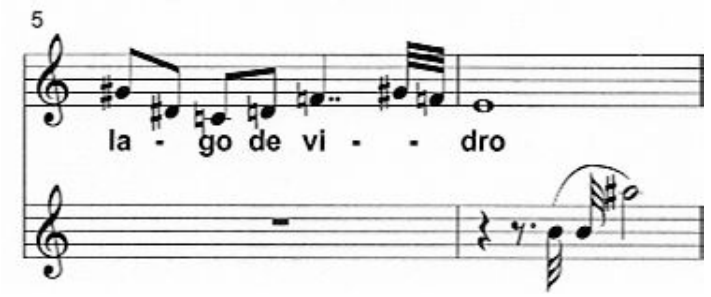

Fonte: MAHLE (1967)

No segmento iniciado no compasso 9 há exploração do idiomatismo de Fórmula de Arpejo pela manutenção da mesma digitação de mão direita. O trecho confere maior densidade na textura de acompanhamento realizado pelo violão.

FIGURA 22 - Epigrafe (1967). Compassos 9-10.

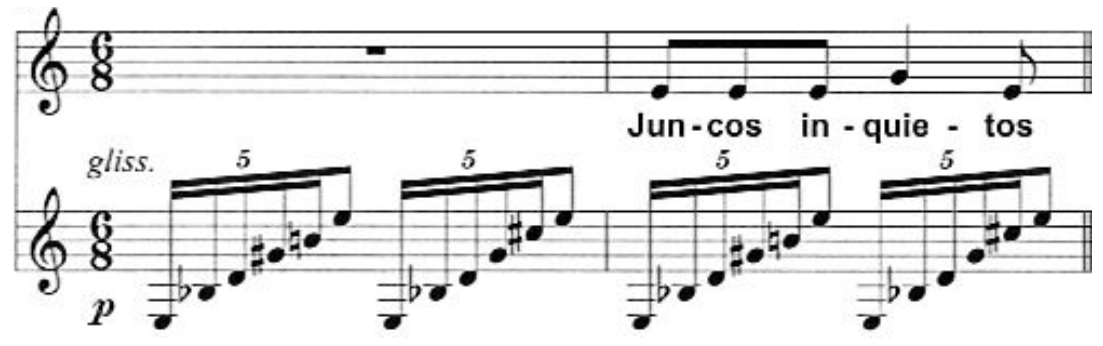

Fonte: MAHLE (1967) 
No compasso 16 apresenta-se mais uma vez um efeito sonoro a partir do idiomatismo de Percussão, sugerido pela marcação “abafar batendo”. Aqui Mahle utiliza o violão para provocar uma cissura em relação ao material de acompanhamento anterior, caracterizado pelas quintinas. Após a Percussão, a voz segue acapella por quatro compassos, em oposição ao segmento anterior, caracterizado pela maior densidade no acompanhamento.

FIGURA 23 - Epigrafe (1967). Compasso 16.

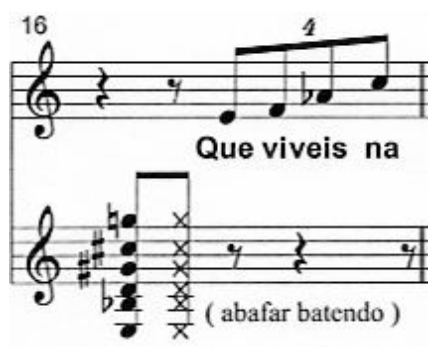

Fonte: MAHLE (1967)

A segunda canção se inicia com uma introdução de dez compassos realizada pelo violão, com exploração de material escalar octatônico. $\mathrm{O}$ andamento Vivo e a figura rítmica do acompanhamento provocam um contraste com a canção anterior, adotando um caráter rítmico. (Fig. 24) Observa-se o idiomatismo de Paralelismo Horizontal com uso de meia-pestana na passagem cromática ascendente nos compassos 7 a 8 . Como veremos em Diálogo para Violão e Cordas, este idiomatismo é recorrente.

FIGURA 24 - Queixa da Moça Arrependida (1967). Compassos 4 - 12.
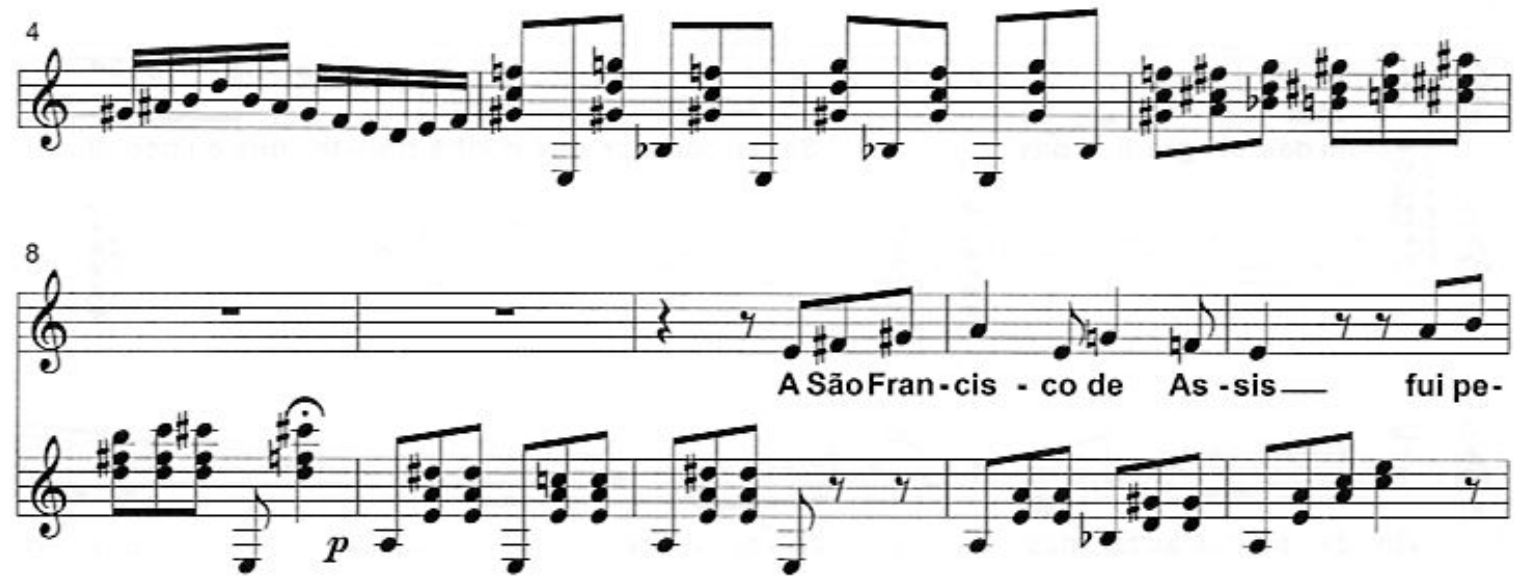

Fonte: MAHLE (1967) 


\subsection{Trios}

Para formação de trio, o catálogo de Mahle apresenta três obras: Trio para flauta, violino e violão (1995), Duas peças para canto, flauta e violão (1974) e Trio para Violino, Violoncelo e Violão (1992). A primeira consiste em uma transcrição da obra Sonata (1985), já mencionada neste artigo, originalmente para violão e violino. Os idiomatismos e materiais composicionais são iguais entre as duas versões. As Duas peças para canto, flauta e violão, foram escritas sobre os textos "Uma flor quebrada" e "A chácara do Chico Bolacha" de Cecília Meirelles e possuem temática infantil, com proposta didática.

A terceira obra, Trio para Violino, Violoncelo e Violão (1992) foi dedicada ao violonista Francesco Biraghi. Não foram encontradas gravações comerciais ou registros audiovisuais da obra. É dividida em três movimentos, Moderato, Andante e Vivace e segue a forma-sonata. O material composicional é predominantemente modal folclórico, com ampla utilização do modo lídio com sétima abaixada. Alguns elementos já indicados em outras obras são também utilizados no Trio, tais como as passagens cromáticas com terças paralelas entre os compassos 119 e 120:

FIGURA 25 - Trio para violino, violoncelo e violão (1992). Compassos 119 - 120.

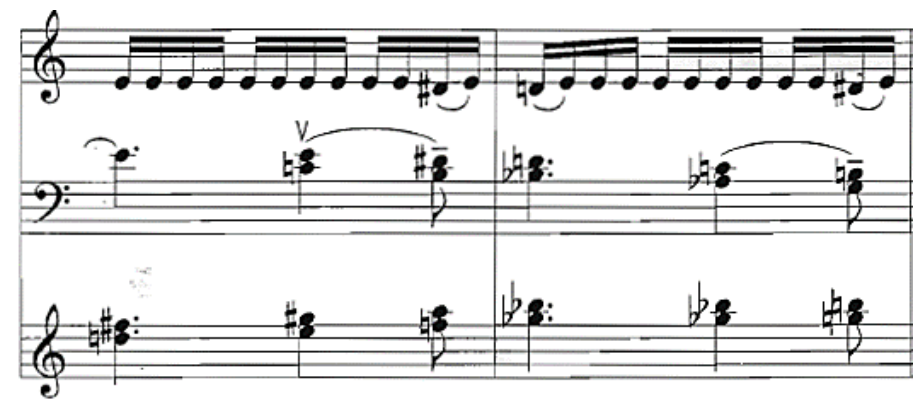

Fonte: MAHLE (1992)

No primeiro e terceiro movimento há predominância de polaridade sobre Lá, e no segundo movimento sobre Mi, o que indica a exploração do Idiomatismo Implícito. Mahle emprega também alguns idiomatismos explícitos na escrita violonística, como no primeiro movimento, em que apresenta acordes com Cordas Soltas e Paralelismos Horizontais com acordes de pestana na segunda e quarta posições do instrumento. 
FIGURA 26 - Trio para violino, violoncelo e violão (1992). Compassos 27 a 29.

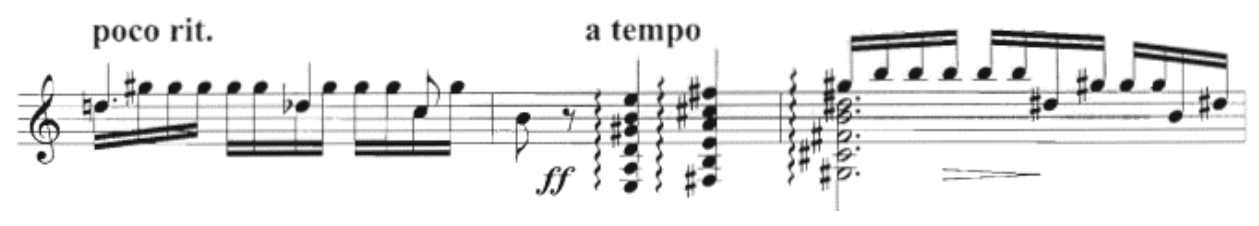

Fonte: MAHLE (1992)

No Andante há utilização do idiomatismo de Harmônicos em todo o movimento. Mahle utiliza este recurso como material básico na constituição de diversos acompanhamentos apresentados pelo violão na peça. Os trechos ilustrados abaixo exemplificam o uso dos harmônicos sobre a décima segunda e décima nona casas do instrumento:

FIGURA 27 - Trio para violino, violoncelo e violão (1992). Andante. Violão. Compassos 1 a 7.

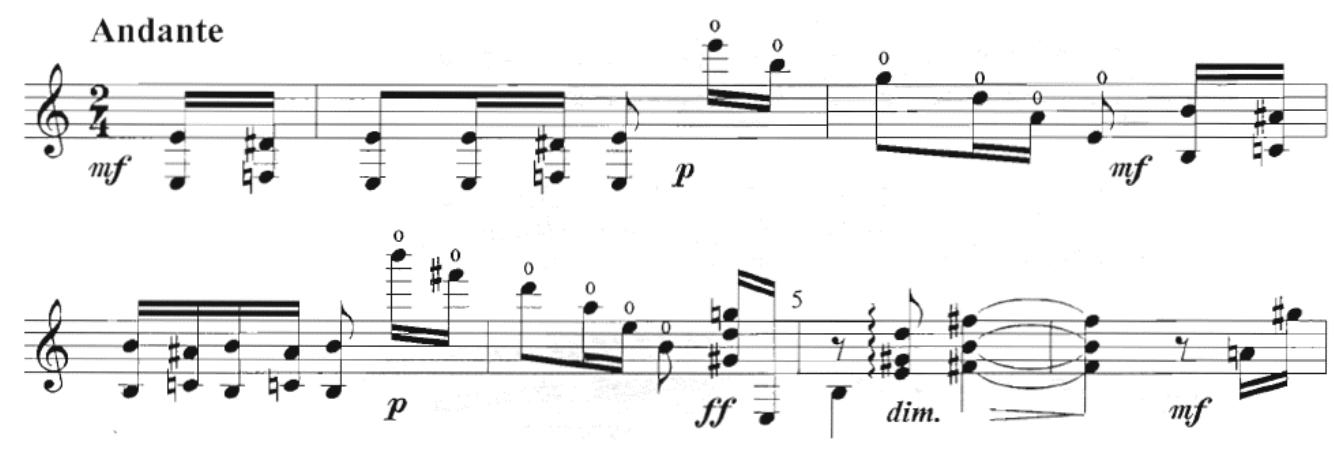

\subsection{Quartetos}

Dentre as formações para quartetos, é relevante uma das mais recentes obras de Mahle, o Quarteto para violóes, de 2015. A obra foi dedicada ao violonista Pieter Rahmeier. Encontramos apenas um registro audiovisual ${ }^{16}$ do primeiro movimento. A obra apresenta três movimentos: Allegro, Andante e Vivo. Mahle utiliza material modal folclórico, intercalado com passagens octatônicas e séries dodecafônicas.

O primeiro movimento é representativo das principais características da escrita de Mahle. Explora um contraste entre duas partes, que se repetem. A primeira parte se inicia com um motivo cromático repetido ao longo da peça (fig. 28) e passagens com escala octatônica em semínimas, com

\footnotetext{
16 Apresentação do Quarteto Toccata. Ver Anexo I.
} 
intervalos de terças entre violóes I e II (fig. 29).

FIGURA 28 - Quarteto para Violôes (2015). Motivo cromático. Violão I. Compassos 1 - 4.

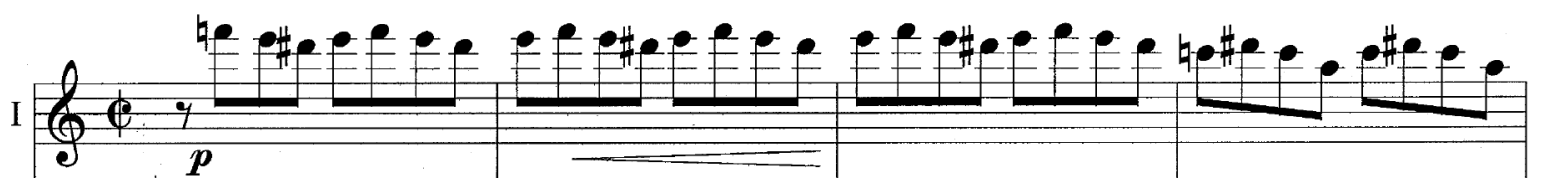

Fonte: MAHLE (2015)

FIGURA 29 - Quarteto para Violões (2015). Violóes I e II. Escala octatônica no Violão I. Compassos 15 e 16.

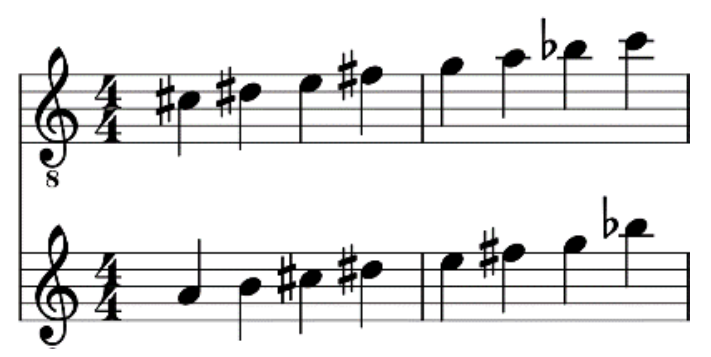

Fonte: MAHLE (2015)

A segunda parte vem com marcação de "calmo" e dinâmica p. Mahle utiliza uma série dodecafônica apresentada em forma imitativa. Inicialmente é exposta no primeiro violão, depois transposta uma quinta abaixo para o segundo violão e finalmente uma quinta abaixo para o quarto violão. A figura 30 contém a apresentação da série dodecafônica (c. 26 - 30) no primeiro violão. A figura 31 contém a apresentação no violão II (c. 30 - 33).

FIGURA 30 - Quarteto para Violões (2015). Série Dodecafônica. Violão I. Compassos 24 - 30; Violão II.

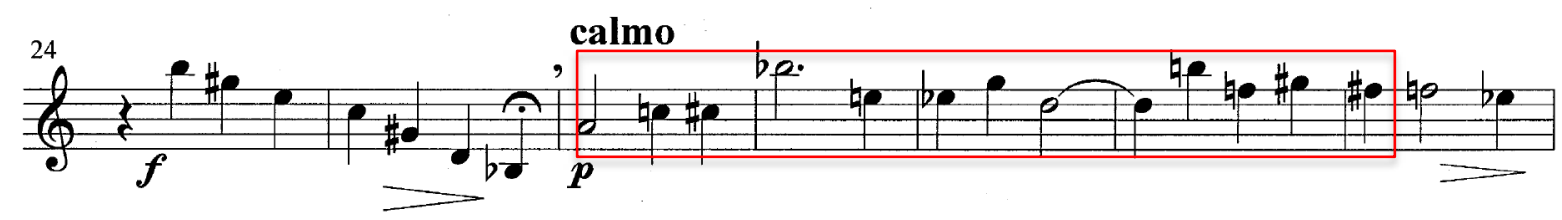

Fonte: MAHLE (2015) 
FIGURA 31 - Quarteto para Violóes (2015). Série Dodecafônica. Violão II. Compassos 26 - 39.
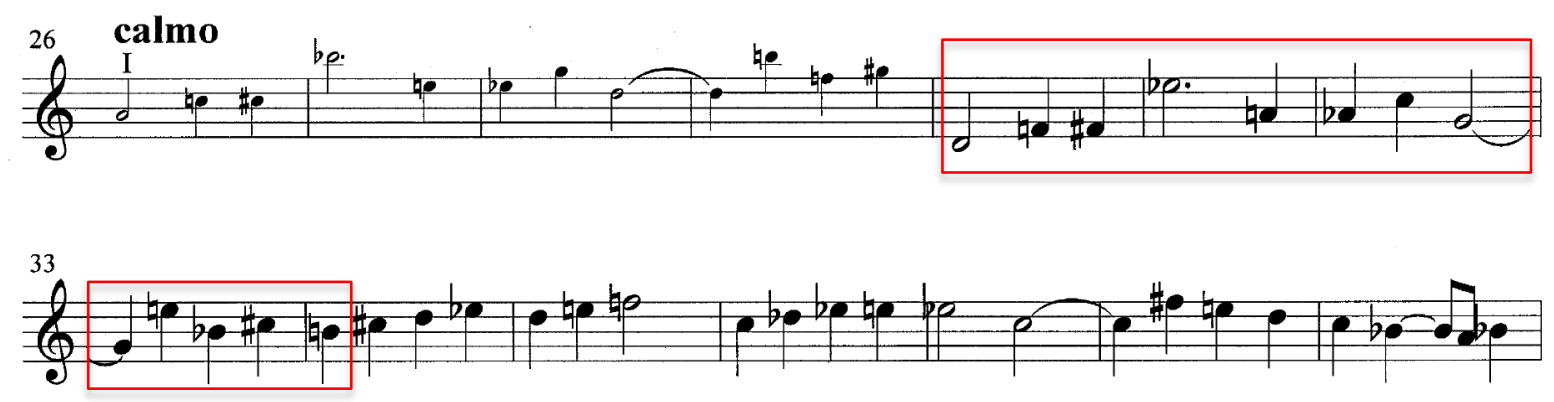

Fonte: MAHLE (2015)

Na reexposição da sessão "Calmo”, a partir do compasso 73, o mesmo tipo de imitativo é apresentado, mas se inicia no quarto violão e segue para o terceiro uma quinta acima, posteriormente para o primeiro e finalmente para o segundo violão. A imagem abaixo representa a exposição no quarto violão e o início da exposição no terceiro violão.

FIGURA 32 - Quarteto para Violóes (2015). Série Dodecafônica. Violão III e IV. Compassos 73 - 77.

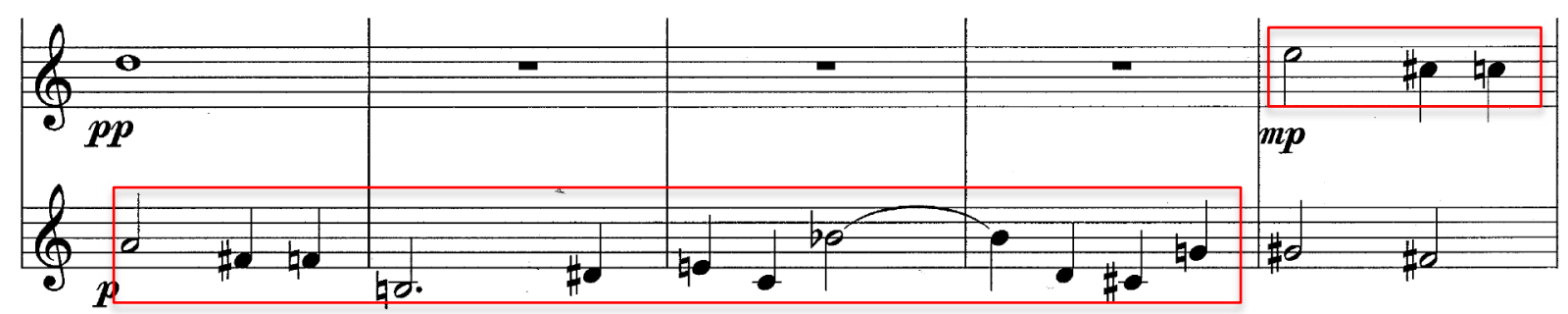

Fonte: MAHLE (2015)

Com sugestão de andamento em $52 \mathrm{bpm}$, o segundo movimento, Andante, contrasta em caráter com o movimento anterior. Explora passagens de escala menor melódica e se fundamenta sobre o tema exposto abaixo.

FIGURA 33 - Quarteto para Violöes (2015). Tema do segundo movimento (Andante). Violão I e II. Compassos 1 - 2.

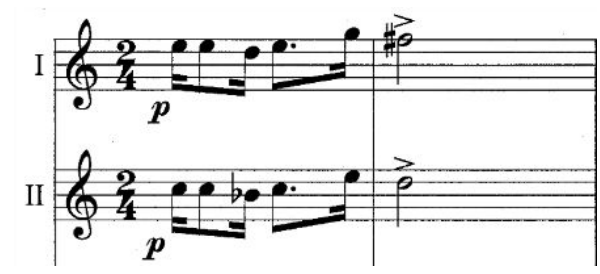

Fonte: MAHLE (2015) 
No terceiro movimento, em andamento rápido, Mahle explora o contraste rítmico entre os violóes pela apresentação de figuras binárias e ternárias em justaposição. A peça se inicia em Lá menor e termina sobre o acorde de Lá maior transitando por regióes harmônicas de Sol menor e Mi maior. Assim, nota-se a utilização do Idiomatismo Implícito. Os idiomatismos explícitos são predominantemente de Rasgueos e acordes com Cordas Soltas. Na figura 34 podemos observar o contraste rítmico nos compassos 44 e 45.

FIGURA 34 - Quarteto para Violöes (2015). Terceiro movimento (Vivo). Compassos 44 - 45.

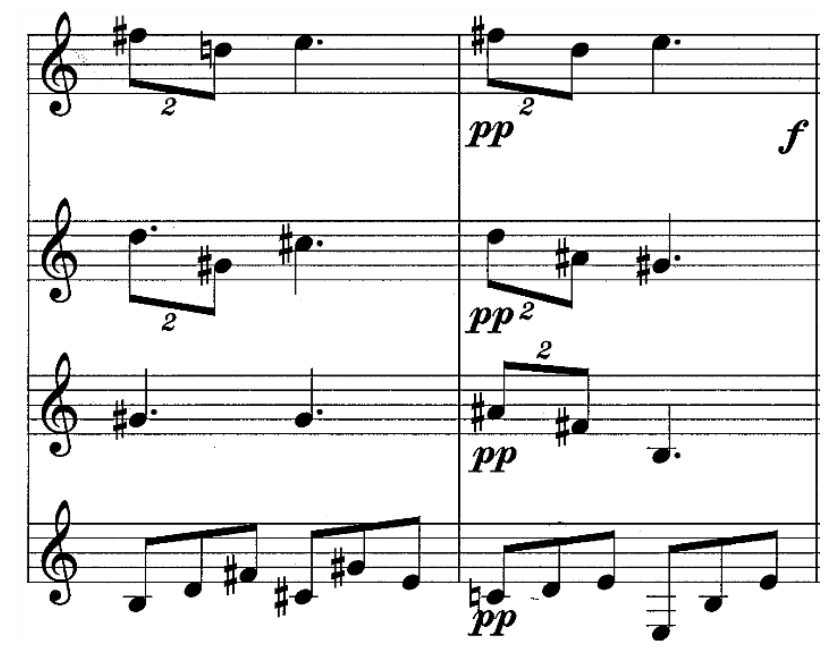

Fonte: MAHLE (2015)

Pela observação da escrita violonística nesta obra, constatamos que não se trata de uma peça com proposta didática, podendo apresentar alguns desafios, principalmente em relação à confluência do grupo. Tampouco há ampla exploração dos idiomatismos explícitos.

\subsection{Quintetos}

No que se refere às obras para quinteto, constam duas peças que são transcrições de obras anteriores. A primeira se trata de uma versão para soprano, flauta, violoncelo, violão e oboé da obra Ou Isto ou Aquilo (1970), originalmente escrita para soprano, flauta, violoncelo e piano. A segunda é uma transcrição para violão e quarteto de cordas da obra Diálogo para violão e cordas (1971), originalmente escrita para violão e orquestra de cordas. A transcrição foi encomendada pelo violonista 
André Rodrigues, tendo sido elaborada por Mahle em 2017. Na obra original é frequente que violoncelo e contrabaixo dobrem a mesma linha. Por esse motivo, não foram necessárias grandes alterações na transcrição. $\mathrm{O}$ compositor transferiu as notas diferentes do contrabaixo para o violoncelo e, os materiais melódicos ou motívicos deste foram transferidos para a viola, permitindo que o violoncelo assumisse a função de preenchimento, no lugar do baixo.

\subsection{Obras Concertantes}

Passamos agora para as obras concertantes escritas por Mahle. Em seu catálogo constam três peças: Concertino sobre um tema espanbol (1970), Diálogo para violão e cordas (1971) e Concertino (2010). A primeira e terceira obras possuem clara proposta pedagógica, o que se observa pela maior facilidade técnica da parte de violão. O Concertino sobre um tema espanbol (1970) se trata de um arranjo que o compositor fez sobre uma melodia folclórica espanhola, para ser executada pelo solista com orquestra infanto-juvenil. Segundo Mahle, esta teria sido escrita com finalidade de ser peça de confronto no Concurso Jovens Instrumentistas, promovido pela escola. (RAHMEIER, 2014, p. 85).

O Concertino (2010) é uma obra para estudante, escrita originalmente para viola de cocho, transcrita em 2010 para violão. Trata-se de uma peça curta, em um movimento, com exploração de material modal mixolídio.

Dentre as peças concertantes para violão escritas por Mahle, Diálogo para violão e cordas (1971) merece destaque. Até o momento é a obra para violão de Mahle com maior número de registros audiovisuais e gravações. É também a única obra que teve gravação comercial integral, feita pelo violonista Marcus Llerena junto à orquestra de câmara Brasil Consort, sob regência de David Chew. A obra foi dedicada ao violonista Sérgio Belluco e teve sua estreia no mesmo ano de composição, com Belluco ao violão e Mahle como regente. O primeiro registro audiovisual é do violonista Fábio Zanon em 1988, no programa Primeiro Movimento, apresentado por Jamil Maluf. Na ocasião, Zanon interpretou a obra junto à Camerata Atheneum, regida por Lucian Rogulski ${ }^{17}$. Possui também uma transcrição para violão e quarteto de cordas, realizada sob encomenda do violonista André Rodrigues em 2017.

17 Ver Anexo I. 
Diálogo para violão e cordas (1971) é constituída de dois movimentos contrastantes: Largo e Vivo. $\mathrm{Na}$ obra Mahle explora predominantemente material modal lídio-mixolídio, escalas octatônicas, de tons inteiros e passagens em material pentatônico. Há predominância de trechos com polaridade sobre as notas Mi e Lá, o que sugere a utilização do idiomatismo implícito da escolha dos centros tonais.

Uma característica fundamental que chama a atenção nesta obra é a maneira como Mahle trabalha o equilíbrio sonoro entre violáo e cordas em sua escrita, permitindo que a obra seja interpretada sem a utilização de sonorização para o violão. Isso se relaciona às questôes estéticofilosóficas do compositor, citadas anteriormente. Mahle se opõe a qualquer tipo de amplificação sonora na interpretação musical, como sugere o excerto abaixo:

\footnotetext{
Até mesmo a amplificação sonora de uma orquestra é vista com reserva pelo compositor, e isso porque o que a corrente antroposófica busca é uma noção de harmonia oriunda da própria natureza, de suas regras de equilíbrio dadas naturalmente e, sob esse prisma, a amplificação funcionaria como uma distorção, uma deformação, em certo sentido, desse equilíbrio.[...] [Mahle] relata como uma negativa experiência um concerto ao ar livre que teve de realizar, a pedido da prefeitura de Piracicaba. Nas palavras do autor teria sido preferível realizar inúmeras vezes o mesmo programa para atender à audiência do que tornar artificial o som da orquestra através da amplificação por microfones. (COSTA, 2010, p. $35)$.
}

Dessa forma, considerando que é comum em obras concertantes para violão a necessidade de sonorização para o solista em função da pequena capacidade de projeção sonora do instrumento frente à orquestra, Mahle opta por soluções de escrita que permitam a audição do violão sem amplificação. Sobre a obra, o compositor afirma:

Eu não cheguei a ouvir, mas me disseram que o concerto do Villa-Lobos sem amplificação é muito difícil. Tem outros que tem orquestra sinfônica completa que acaba com o violão. Então tive a ideia de fazer o Diálogo, onde o violáo toca e depois a orquestra toca o tutti e de vez em quando acompanha o violão. Foi uma forma bastante ideal. (RAHMEIER, 2014, p. 85.)

Além da alternância entre violão e cordas em um diálogo, como sugere o título da obra, Mahle utiliza uma série de escolhas composicionais de forma a equilibrar solista e cordas. Como pontua Zanon, sobre esta característica da obra: "O que chama a atenção logo de cara é o equilíbrio. O violão se escuta sem nenhum esforço e sem nenhuma amplificação.” (ZANON, 2007) 
Nos momentos em que violão e cordas tocam juntos, o destaque da linha solista é feito de diferentes maneiras. Em alguns trechos, Mahle evidencia a linha solista pela redução da dinâmica orquestral, permitindo que uma melodia ou tema seja realizado pelo violão. Em outros momentos, Mahle alterna violão e cordas nos papéis primários e secundários, em exposição de motivos ou acompanhamentos. Outra forma de destacar o violão é realizada pela diferenciação rítmica, de modo que um motivo é apresentado pelo violão em figuras rítmicas que contrastam com o acompanhamento orquestral. Também se utiliza da diferenciação entre solista e orquestra pelo afastamento de registro, de modo que a linha solista se torna audível em função do registro no qual foi colocado, consideravelmente afastado do registro orquestral naquele trecho. (ARCE, 2019). ${ }^{18}$

No que se refere aos materiais composicionais, notamos que Mahle se utiliza do modalismo intercalado com passagens pentatônicas e segmentos com passagens escalares octatônicas e de tons inteiros. Aqui fica latente a mescla entre materiais que fazem referência ao folclore e os materiais de inspiração vanguardista. No trecho abaixo, no segundo movimento, observa-se a utilização de material mixolídio com centro em Lá:

FIGURA 35 - Diálogo para violão e cordas (1971). II. Vivo. Violão. Compassos 96 - 99.

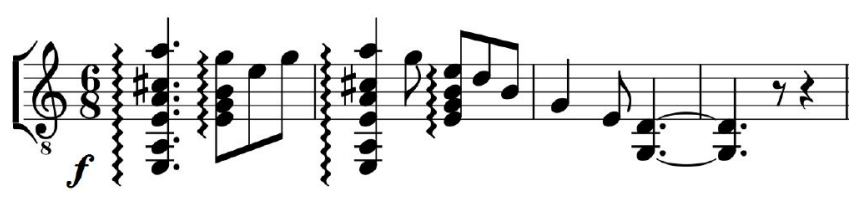

Fonte: MAHLE (1971)

O trecho abaixo exemplifica o uso de material pentatônico maior de Lá, na codetta que encerra o primeiro movimento:

FIGURA 36 - Diálogo para violão e cordas (1971). I. Largo. Redução para piano. Compassos 75 - 79.

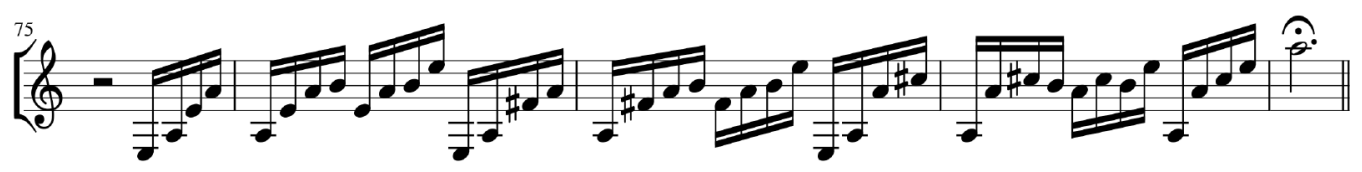

Fonte: MAHLE (1971)

$18 \mathrm{O}$ estudo da escrita de Mahle que permite o equilíbrio sonoro entre violão e cordas nesta obra é tratado em Arce (2019). 
No segundo movimento Mahle também explora passagens escalares octatônicas e de tons inteiros. No trecho abaixo o violão apresenta uma escala de tons inteiros iniciada em Fá, que é entrecortada pelas cordas apresentando material de Fá mixolídio/lídio e em sequência uma passagem de escala octatônica no violão.

FIGURA 37 - Diálogo para violão e cordas (1971). II. Vivo. Redução para piano. Compassos 248 - 253.

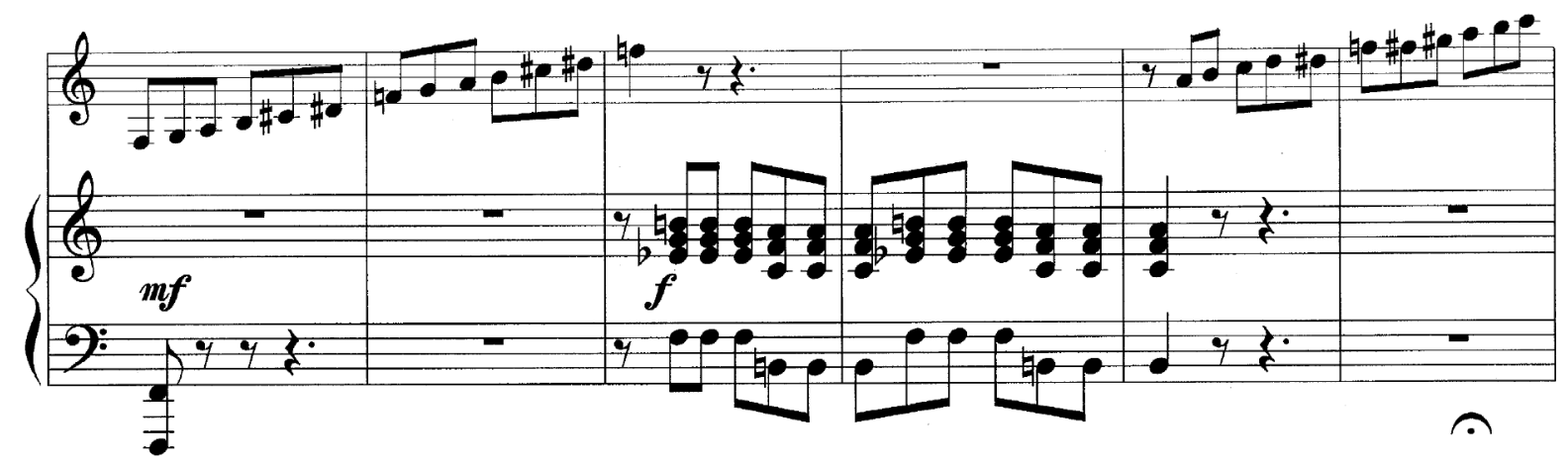

Fonte: MAHLE (1971)

No tocante aos idiomatismos da linha solista, Mahle explora os Paralelismos Verticais e Horizontais, Fórmulas de Arpejo, Percussões, uso de Campanella e Rasgueados, além do Idiomatismo Implícito dos centros tonais de Mi e Lá. No primeiro movimento, Largo, um exemplo da utilização de fórmula de arpejo é observado no compasso 35, em que a sequência de arpejos é realizada com o mesmo padrão de mão direita:

FIGURA 38 - Diálogo para violão e cordas (1971). I. Largo. Violão. Compassos 35 - 37.

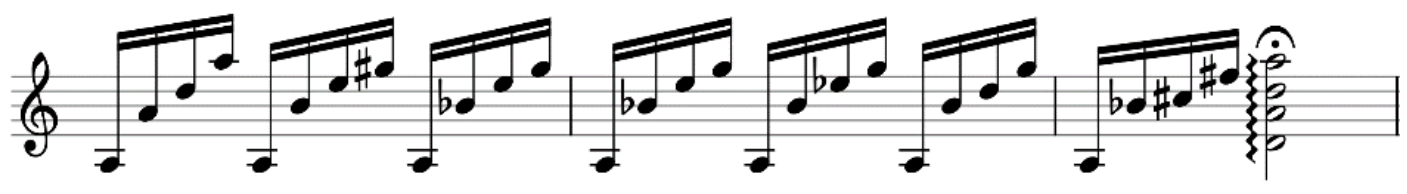

Fonte: MAHLE (1971)

Os paralelismos horizontais podem ser observados nas passagens que exploram os intervalos de quartas, que podem ser tocados com pestanas ou meias-pestanas em diferentes posiçóes da escala. $\mathrm{O}$ trecho abaixo exemplifica seu uso. 
FIGURA 39 - Diálogo para violão e cordas (1971). Segundo movimento (Vivo). Violão. Compassos 111 - 117.

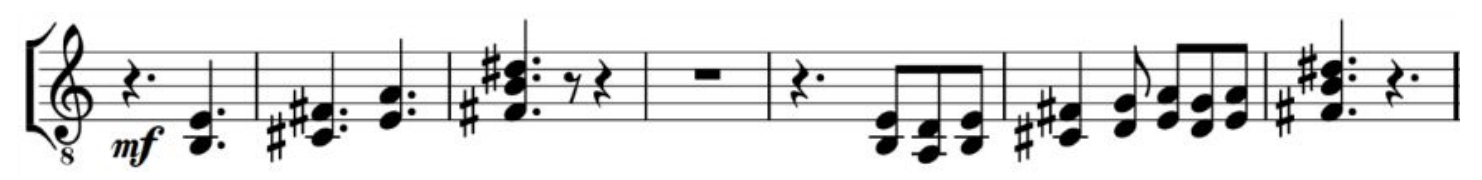

Fonte: MAHLE (1971)

No segmento abaixo observa-se um tipo de Paralelismo Horizontal, pelo traslado da pestana de mão esquerda e ligados realizados com o dedo 3 ao longo de diferentes posições da escala.

FIGURA 40 - Diálogo para violão e cordas (1971). Segundo movimento (Vivo). Violão. Compassos 178 - 184.

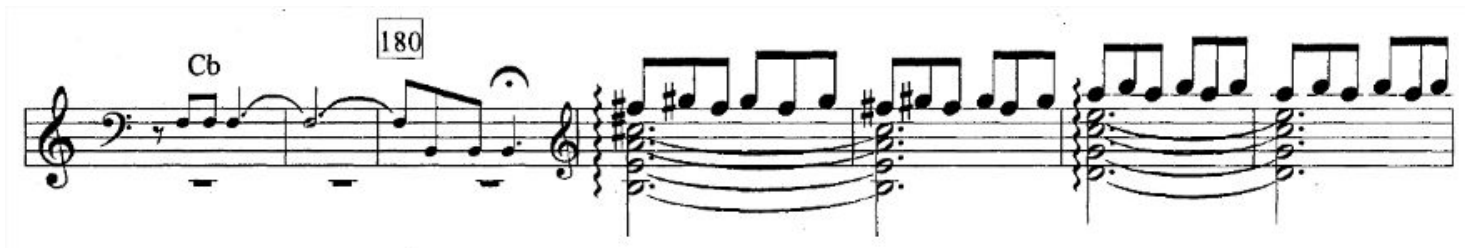

Fonte: MAHLE (1971)

A utilização dos Rasgueados pode ser observada em dois momentos do segundo movimento, sendo um destes representado abaixo, com marcação de "rondalla”

FIGURA 41 - Diálogo para violão e cordas (1971). Segundo movimento (Vivo). Violão. Compassos 145 - 147.

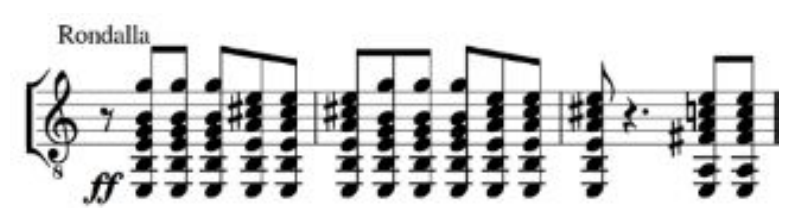

Fonte: MAHLE (1971)

$\mathrm{Na}$ Figura 42 observamos um exemplo de exploração do idiomatismo de Cordas Soltas. Mantendo a mesma posição de mão esquerda e ligados entre os dedos 1 e 2, Mahle gradualmente adiciona notas correspondentes às cordas soltas do instrumento. 
FIGURA 42 - Diálogo para violão e cordas (1971). Segundo movimento (Vivo). Violão. Compassos 160 - 164.

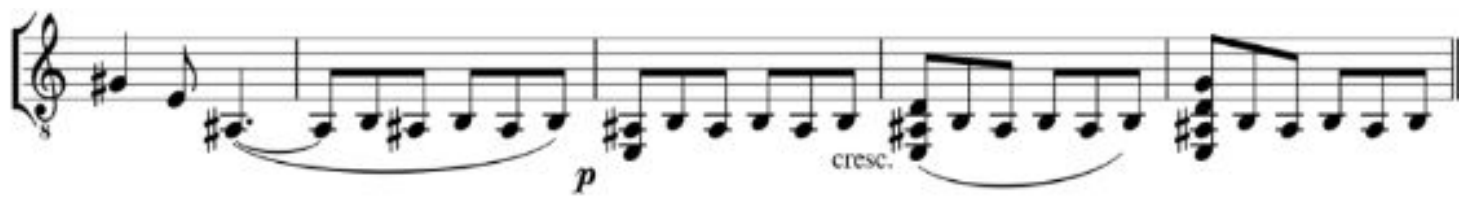

Fonte: MAHLE (1971)

Assim, observa-se que a escrita idiomática e o trabalho de equilíbrio acústico no Diálogo para violão e cordas conferem grande potencial didático à peça, no sentido de ser uma obra introdutória às práticas concertantes. Como afirma Zanon (2007): “num mundo ideal, esta seria a primeira experiência de todo estudante como solista de orquestra”.

\section{Conclusões}

A partir do olhar sobre a obra para violão de Ernst Mahle, foi possível chegar a algumas características centrais:

1. Em linhas gerais, é possível estabelecer uma divisão entre as obras com proposta pedagógica e obras que demandam maior conhecimento/experiência musical e domínio técnico por parte do instrumentista.

2. O uso de idiomatismos é algo que permeia a maior parte das peças que incluem violão, independentemente de estas terem ou não uma proposta pedagógica.

3. Em relação à exploração do Idiomatismo Implícito, na maior parte das obras, Mahle escolhe uma polaridade sobre Lá e Mi, o que favorece a sonoridade do instrumento.

4. Em diversas obras Mahle trabalha o material modal de inspiração folclórica sobre formas tradicionais, como a forma-sonata.

5. Há maioria de obras para música de câmara.

6. O violão é abordado em diversas formações e com funções distintas dentro das obras do compositor, mas quase sempre assume uma posição de protagonista, ou ao menos de igual hierarquia em relação aos demais instrumentos com os quais dialoga.

7. O material composicional é majoritariamente caracterizado pela mescla entre o 
modalismo de inspiração folclórica e materiais característicos da música do século XX. Predominam os materiais escalares: lídio, mixolídio, a combinação destes (pelo quarto grau aumentado e sétimo abaixado), octatônico, de tons inteiros, dodecafônico e pentatônico.

Embora a obra para violão de Ernst Mahle venha ganhando cada vez mais a atenção de pesquisas e trabalhos acadêmicos, não recebeu ainda - ao que parece - maior conhecimento por parte dos intérpretes. De sua profícua produção para violão, que reúne desde obras solistas até mais de 13 combinações camerísticas, apenas três obras receberam gravaçôes comerciais. Além do potencial didático contido nas peças com proposta pedagógica, existe um grande número de obras que exploram as capacidades sonoras e expressivas do violão de maneira eclética em uma escrita extremamente idiomática.

\section{REFERÊNCIAS}

ARCE, Guilherme Luis Bassi. Estudo do equilíbrio sonoro no concerto Diálogo para violão e cordas de Ernst Mahle. In: SIMPÓSIO: PANORAMA DA PESQUISA SOBRE VIOLÃO NO BRASIL. Congresso da ANPPOM. N. 29. Pelotas/RS: ANPPOM, 2019, 1 - 9.

ARZOLLA, Antônio Roberto Roccia Dal Pozzo. Uma Abordagem Analitico-interpretativa do Concerto 1990 para Contrabaixo e Orquestra de Ernst Mable. 1996. Dissertação (Mestrado em Música Brasileira). Universidade do Rio de Janeiro, Rio de Janeiro, 1996.

BARROS, Guilherme Antonio Sauerbronn de. Goethe e o Pensamento Estético-Musical de Ernst Mable: um Estudo do Conceito de Harmonia. 2005. Tese (Doutorado em Musicologia). Universidade Federal do Estado do Rio de Janeiro, Rio de Janeiro, 2005.

COSTA, Flávio Collins. Um Estudo de Três Obras Sinfônicas de Ernst Mable: o encontro entre o compositor e o pedagogo. 2010. Dissertação (Mestrado em Música). Universidade Federal do Estado do Rio de Janeiro, Rio de Janeiro, 2014.

FARIAS, Priscila Araújo. A escrita idiomática da rabeca ao violino: Guerra-Peixe e a sonoridade nordestina. Revista Brasileira de Música, Rio de Janeiro, v. 26, n. 1, 105-129, 2013.

FERNANDES, Vinícius de Lucena, 2014. Suite para Violão Solo de Ernst Mable: Uma abordagem técnica e interpretativa. Dissertação (Mestrado em Música). 2014. Universidade de Aveiro, Aveiro, Portugal. 2014.

KREUTZ, Thiago de Campos. A música para violão solo de Edino Krieger: um estudo do idiomatismo técnico-instrumental e processos composicionais. 2014. Dissertação (Mestrado em Música). 
Universidade Federal de Goiás, Goiânia, 2014.

LANZ, Rudolf. A pedagogia Waldorf: Caminho para um Ensino Mais Humano. Edição de 2002. São Paulo: Summus Editorial. 1979.

LLERENA, Marcus. Noturno Brasileiro. Rio de Janeiro, Brasil: Gravação independente, 1991. CD. . Toque Solo. Joinville-SC, Brasil: Gravação independente, 2007. CD.

LUNA, Iradi Tavares de. Quarteto para contrabaixos 1995 de Ernst Mable: análise interpretativa. Dissertação (Mestrado em Música). 2013. Universidade Federal da Paraíba, João Pessoa, 2013.

MAHLE, Ernst. As Melodias da Cecilia (1970). Piracicaba-SP, Brasil. Associação Amigos Mahle, 2003. Partitura, 57 p. Violão.

Catálogo. $61 \mathrm{p}$. . Catálogo de Obras 2018. Associação Amigos Mahle. Piracicaba-SP, Brasil. 2018.

- Diálogo para violão e cordas (1971). Piracicaba-SP, Brasil. Associação Amigos Mahle, 1971. Partitura, 67 p. Violão; Violinos, Viola, Violoncelo, Contrabaixo. . Suitepara Violão Solo (1975). Piracicaba-SP, Brasil. Manuscrito. 1975. 14 p. Violão. 1975. 14 p. Violão. . Suite para Violão Solo (1975). Piracicaba-SP, Brasil. Associação Amigos Mahle, 1975. 6 p. Violão.

. Três Peças para Violão (1975). Piracicaba-SP, Brasil. Associação Amigos Mahle, . Sonata para Violino e Violão (1985). Piracicaba-SP, Brasil. Associação Amigos Mahle, 1985. 20 p. Violão e Violino.

- Trio para Violino, Violão e Violoncelo (1992). Piracicaba-SP, Brasil. Associação Amigos Mahle, 1992. 25 p. Violão, Violino e Violoncelo.

p. Dois violóes.

. Duetos Modais (2015). Piracicaba-SP, Brasil. Associação Amigos Mahle, 2015. 16

. Sonatina para violão e piano (2015). Piracicaba-SP, Brasil. Associação Amigos Mahle, 2015. 14 p. Violão e Piano.

PINTO, Aloysio de Alencar. A melodia do Nordeste e suas constantes modais. Revista do Instituo do Ceará, Fortaleza, n. 108, 237 - 246, 1994.

RAHMEIER, Pieter. Suite para violão de Ernst Mable: uma edição critica e de performance. Dissertação (Mestrado em Música).2014. Universidade Federal de Goiás, Goiânia. 2014.

RAHMEIER, Pieter; AGUIAR, Werner. O processo da escolha de digitação das Três peças para violão (1975) de Ernst Mahle. In: CONGRESSO DA ANPPOM. Natal, N.23, 2013, Natal. Associação Nacional de Pesquisa e Pós-Graduação em Música, 2013. 1 - 10.

SCARDUELLI, Fábio. A obra Para Violão Solo de Almeida Prado. Dissertação (Mestrado em Música). 2007. Universidade Estadual de Campinas. Campinas, 2007.

SUAREZ, Rosana. Nota sobre o conceito de Bildung (formação cultural). Kriterion, Belo 
Horizonte, v. 46, n. 112, p.191-198, 2005.

TACUCHIAN, Ricardo. Estrutura e estilo na obra de Béla Bartók. Revista Brasileira de Música, Rio de Janeiro, N. 21, 1 - 17 do artigo, 1994-95.

TOKESHI, Eliane. Ernst Mable: Violin Sonatas and Sonatinas (1955-80). Tese (Doutorado em Música). 1999. Northwestern University. Evanston, Illinois, Estados Unidos. 1999.

ZANON, Fábio. Programa Violão com Fábio Zanon. Rádio Cultura FM. 2007. Ed. N. 75. Disponível em: <http://vcfz.blogspot.com/ >. Acesso em: 29/08/2020.

\section{SOBRE OS AUTORES}

Guilherme Arce é Mestre em Estudos Instrumentais e Performance Musical pela Universidade Estadual de Campinas. É Bacharel em Violão Erudito e em Ciências Econômicas pela mesma instituição. Seus trabalhos e pesquisas abordam os temas: violão brasileiro, análise musical, performance musical e pedagogia do instrumento. ORCID: https://orcid.org/0000-0002-3780-0613. E-mail: arce.guilherme@gmail.com

Fábio Bartoloni é Doutor em Performance pela Arizona State University, onde foi professor assistente e recebeu a Bolsa de Estudos Richard and Babette Burns. Ao final do curso foi escolhido como Outstanding Graduate entre todos os formandos em Artes. Também é Mestre em Música pelo Instituto de Artes da UNESP. Recebeu o Joan Frazer Memorial Award 2016-2017. Lecionou em diversas instituições, tais como Conservatório Villa-Lobos da FITO, FAC-FITO, EMESP Tom Jobim, Guri Santa Marcelina, além de ter lecionado Violão e Música de Câmara no Instituto de Artes da UNESP. Atualmente é Professor de Violão da Universidade do Estado do Amapá. ORCID: https://orcid.org/00000001-9224-0375. E-mail: fabio.bartoloni@gmail.com 


\section{ANEXO I - LISTAGEM DE REGISTROS E GRAVAÇÕES DAS OBRAS}

\begin{tabular}{|c|c|c|c|c|c|}
\hline Obra & Intérprete(s) & Ano & $\begin{array}{l}\text { Tipo de } \\
\text { Registro }\end{array}$ & $\begin{array}{c}\text { Outras } \\
\text { informações }\end{array}$ & Disponível em: ${ }^{19}$ \\
\hline \multirow{3}{*}{ Suíte (1975) } & Vinícius Lucena Fernandes & 2019 & audiovisual & - & $\begin{array}{l}\text { youtube.com/watch } \\
? \mathrm{v}=\mathrm{ezN} \text { 0wxMVC4 }\end{array}$ \\
\hline & Álvaro Henrique & 2007 & áudio & - & $\begin{array}{l}\text { http://vcfz.blogspot } \\
\text {.com/2007/05/75- } \\
\underline{\text { ernst-mahle.html }}\end{array}$ \\
\hline & Marcus Llerena & 2007 & áudio & $\begin{array}{l}\text { CD: "Toque } \\
\text { Solo". Gravação } \\
\text { Independente: I. } \\
\text { Rapsódia; II. } \\
\text { Moto Perpétuo } \\
\end{array}$ & - \\
\hline $\begin{array}{l}\text { Duetos Modais } \\
\qquad(2015)\end{array}$ & $\begin{array}{l}\text { Beatriz Virgínia; Gabriel } \\
\text { Costa }\end{array}$ & 2020 & audiovisual & - & $\begin{array}{l}\underline{\text { https://www.youtu }} \\
\underline{\text { be.com/watch?v=IS }} \\
\underline{\text { mmM3CId6c }}\end{array}$ \\
\hline \multirow{4}{*}{ Sonata (1985) } & $\begin{array}{c}\text { Tânia Camargo Guarnieri } \\
\text { (violino); Francesco Biraghi } \\
\text { (violão) }\end{array}$ & 2009 & áudio & $\begin{array}{l}\text { CD: "Viaggio a } \\
\text { colori". Smc } \\
\text { Records. }\end{array}$ & 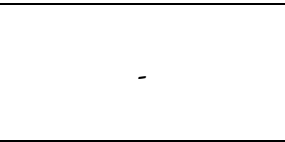 \\
\hline & $\begin{array}{l}\text { Franco Mezzena (violino); } \\
\text { Eros Roselli (violão) }\end{array}$ & 2016 & audiovisual & 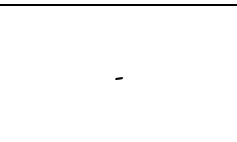 & $\begin{array}{l}\frac{\text { https://www.youtu }}{\text { be.com/watch?v=ls }} \\
\underline{\mathrm{yC} 8 \mathrm{kSNDmM}}\end{array}$ \\
\hline & $\begin{array}{c}\text { Jeff Anvinson (violão); Eric } \\
\text { Lawson (violino) }\end{array}$ & 2009 & audiovisual & - & $\frac{\underline{\text { https://www.youtu }}}{\text { be.com/watch?v=4v }}$ \\
\hline & $\begin{array}{c}\text { Fábio Zanon (violão); Celisa } \\
\text { Frias (violino) }\end{array}$ & 2007 & áudio & $\begin{array}{c}\text { Programa violão } \\
\text { com Fábio } \\
\text { Zanon }\end{array}$ & $\begin{array}{c}\text { http://vcfz.blogspot } \\
. \text { com/2007/05/75- } \\
\text { ernst-mahle.html }\end{array}$ \\
\hline Sonatina (2015) & $\begin{array}{l}\text { Gerelmager Gonçalves } \\
\text { (violão); Cidinha Mahle } \\
\text { (piano) }\end{array}$ & 2015 & áudio & - & $\begin{array}{l}\text { http://www.emahle. } \\
\frac{\text { com/Music/sonatin }}{\text { aforguitarandpiano/ }} \\
\frac{\text { sonatinaforguitaran }}{\text { dpiano.html }}\end{array}$ \\
\hline Natal (1987) & $\begin{array}{l}\text { Renato Mendes (violão); } \\
\text { Luísa Voigt (soprano) }\end{array}$ & 2015 & audiovisual & - & $\frac{\underline{\text { https://www.youtu }}}{\text { be.com/watch?v=A- }}$ \\
\hline $\begin{array}{l}\text { Quarteto para } \\
\text { violóes }(2015)\end{array}$ & $\begin{array}{c}\text { Jardel Tartari; Marcos } \\
\text { Araújo; Pieter Rahmeier; } \\
\text { Rafael Salgado }\end{array}$ & 2015 & audiovisual & - & $\begin{array}{l}\underline{\text { https://www.youtu }} \\
\text { be.com/watch?v=pl } \\
\underline{\text { A0mcgB_ao }}\end{array}$ \\
\hline $\begin{array}{c}\text { Diálogo para } \\
\text { violão e cordas } \\
\text { (1971) arr. Para } \\
\text { quinteto }\end{array}$ & $\begin{array}{l}\text { André Rodrigues (violão); } \\
\text { Grégor Monlun (violino); } \\
\text { Isaac Jobin (violino); Sarah } \\
\text { Martineau (viola); Jean- } \\
\text { Christophe Lizotte } \\
\text { (violoncelo) }\end{array}$ & 2018 & audiovisual & - & $\begin{array}{l}\underline{\text { https://www.youtu }} \\
\frac{\text { be.com/watch?v=w }}{\text { lCchOSU9Y }}\end{array}$ \\
\hline
\end{tabular}

${ }^{19}$ Último acesso dos links: 27/10/2020. 
ANEXO I - (cont.) LISTAGEM DE REGISTROS E GRAVAÇÕES DAS OBRAS

\begin{tabular}{|c|c|c|c|c|c|}
\hline Obra & Intérprete(s) & Ano & $\begin{array}{c}\text { Tipo de } \\
\text { Registro }\end{array}$ & $\begin{array}{c}\text { Outras } \\
\text { informaçôes }\end{array}$ & Disponível em: \\
\hline \multirow{4}{*}{$\begin{array}{l}\text { Diálogo para } \\
\text { violão e cordas } \\
\quad(1971)\end{array}$} & $\begin{array}{c}\text { José Henrique de Campos } \\
\text { (violão); NEOJIBA } \\
\text { (orquestra); Eduardo Torres } \\
\text { (regência) }\end{array}$ & 2019 & audiovisual & - & 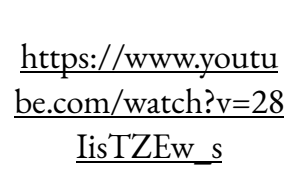 \\
\hline & $\begin{array}{l}\text { Daniel S. Mendes (Violão); } \\
\text { Antônio Borges-Cunha } \\
\text { (Regência); Orquestra de } \\
\text { Câmara Sesi/FUNDARTE }\end{array}$ & 2012 & audiovisual & - & $\begin{array}{l}\frac{h t t p s: / / \text { www.youtu }}{\text { be.com } / \text { watch?v }=\mathrm{P}} \\
\text { BFAPQ2PRRw }\end{array}$ \\
\hline & $\begin{array}{l}\text { Fábio Zanon (violão); } \\
\text { Lucian Rogulski (regência); } \\
\text { Camerata Atheneum }\end{array}$ & 1988 & audiovisual & $\begin{array}{l}\text { Programa } \\
\text { Primeiro } \\
\text { Movimento }\end{array}$ & $\begin{array}{l}\underline{\text { https://www.youtu }} \\
\text { be.com } / \text { watch?v=N } \\
\frac{\text { bXTkfBxET4\&t }=1}{226 \mathrm{~s}}\end{array}$ \\
\hline & $\begin{array}{l}\text { Marcus Llerena (violão); } \\
\text { David Chew (regência); } \\
\text { Brasil Consort }\end{array}$ & 1991 & áudio & $\begin{array}{l}\text { CD "Noturno } \\
\text { Brasileiro" }\end{array}$ & - \\
\hline
\end{tabular}

